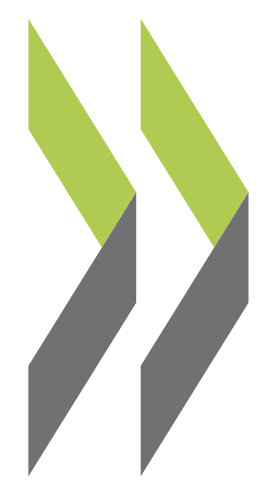

OECD Working Papers on Finance, Insurance and Private Pensions No. 45

The changing structure of financial intermediation Caroline Roulet in Asia: Benefits and risks 
OECD Working Papers should not be reported as representing the official views of the OECD or of its member countries. The opinions expressed and arguments employed are those of the authors.

Working Papers describe preliminary results or research in progress by the author(s) and are published to stimulate discussion on a broad range of issues on which the OECD works. Comments on Working Papers are welcomed, and may be sent to daf.contact@oecd.org or the Financial Affairs Division, Directorate for Financial and Enterprise, OECD, 2 rue André-Pascal, 75775 Paris Cedex 16, France.

\section{OECD Working Papers on Finance, Insurance and Private Pensions}

Selected studies on finance, insurance and private pensions policy prepared for dissemination in order to stimulate wider discussion and further analysis and obtain feedback from interested audiences. The studies provide timely analysis and background on industry developments, structural issues, and public policy in the financial sector. Topics include risk management, governance, investments, benefit protection, and financial education. Previous papers addressing these policy issues are available via http://dx.doi.org/10.1787/19936397

OECD Working Papers on Finance, Insurance
and Private Pensions
are published on https://doi.org/10.1787/20797117

This document and any map included herein are without prejudice to the status of or sovereignty over any territory, to the delimitation of international frontiers and boundaries and to the name of any territory, city or area. publications, databases and multimedia products in your own documents, presentations, blogs, websites and teaching materials, provided that suitable acknowledgment of OECD as source and copyright owner is given. All requests for commercial use and translation rights should be submitted to rights@oecd.org. 


\title{
The changing structure of financial intermediation in Asia: Benefits and risks
}

by

Caroline Roulet ${ }^{*}$

\begin{abstract}
Over the past two decades, Asian economies have experienced rapid capital market growth and profound changes in the structure of their financial systems. This paper analyses key developments in advanced and emerging Asian economies since the global financial crisis, focusing on market intermediation of sovereign and corporate debt, equity market development, and the growth of alternative finance and structured products. This enables a forward-looking assessment of the extent to which developments in the medium term may contribute to rising risks in the stability of financial intermediation and sustainable long-term growth with a view to informing policy discussions on economic opportunities and associated risks.
\end{abstract}

Authorised for release by Greg Medcraft, Director, OECD Directorate for Financial and Enterprise Affairs Keywords: Capital markets, debt sustainability, non-bank financial intermediation.

JEL Codes: F34, F42, G21, G23.

"Caroline Roulet is Economist and Policy Analyst in the OECD Directorate for Financial and Enterprise Affairs. 


\section{Table of Contents}

The changing structure of financial intermediation in Asia: Benefits and risks

1. Introduction

2. Debt markets

2.1. Sovereign debt

2.2. Corporate debt

3. Market-based finance and Fintech credit in Asia 16

3.1. The rise of market-based finance 16

3.2. The increasing importance of non-bank credit intermediation $\quad 19$

3.3. The rapid growth of FinTech credit 23

$\begin{array}{ll}\text { 4. Equity markets } & 27\end{array}$

5. Summary and conclusions $\quad 31$

References 33

Annex A. Economic and Financial linkages between Hong Kong, China, and Mainland China 36

Annex B. ICOs and SME financing $\quad 44$

Annex C. List of previously published working papers $\quad 46$

$\begin{array}{ll}\text { Notes } & 49\end{array}$

Tables

Table 3.1. Total Fintech volume by region and model categories, 2018

Figures

Figure 2.1. Sovereign and non-financial sector total outstanding debt, 2000-2019

Figure 2.2. Sovereign debt and budget deficit to GDP for selected Asian economies, 2007 versus 2019

Figure 2.3. Amount of local currency sovereign debt with a maturity less than 5 years for selected Asian economies, 2007 versus 2019 
Figure 2.4. Corporate bonds outstanding globally, 1997-2019

Figure 2.5. Nominal corporate debt issuance and outstanding debt-to-GDP for selected Asian economies, 2002-2019

Figure 2.6. Non-financial listed companies' debt to EBITDA ratio for selected economies, 2004-2019

Figure 2.7. Speculative grade corporate defaults, 1994-2018

Figure 2.8. Amount of local currency corporate debt with a maturity less than 5 years for selected Asian economies, 2007-2018

Figure 3.1. The relative size of the financial sector in selected economies, 2007-2018

Figure 3.2. The structure of the financial sector by categories of financial institutions in selected economies, 2007-2018

Figure 3.3. The structure of the financial sector by categories of financial institutions in selected Asian economies, 2007-2018

Figure 3.4. The absolute and relative size of the shadow banking sector in selected economies, 2018

Figure 3.5. The assets of banks and the shadow banking sector in China, 2006-2019

Figure 3.6. Total FinTech volume, 2015-2018

Figure 3.7. Selected Chinese lending interest rates, 2013-2018

Figure 3.8. Cumulative failed FinTech lending platforms in China, 2013-2019

Figure 4.1. Share of Asian non-financial companies in global public equity financing, 2000-2018 27

Figure 4.2. Technology IPO proceeds, as a percentage of total IPO proceeds, 2006-2017

Figure 4.3. Initial Coin Offering (ICO) proceeds as a share of global IPO proceeds, 2014-2018 28

Figure 4.4. Distribution of global issuance of ICOs by domiciliation, 2014-2018

Figure 4.5. Non-financial listed companies' debt to equity ratio for selected Asian economies, 2004-2019 30

Figure 4.6. Non-financial listed companies' EBITDA to equity ratio for selected Asian economies, 2004-2019 30

Figure 0.1 . The ICO process and related risks 


\section{Introduction}

Over the past two decades, Asian economies have experienced rapid capital market growth and profound changes in the structure of their financial systems. In particular, Asian companies have become the largest users of global public equity markets. This combined with growth in corporate bond markets has offered investors and firms greater diversification and opportunities for their financial portfolios. Capital market development has also expanded financing sources for companies. In parallel, financial sector growth has been observed in many emerging Asian economies with the rise of market-based finance and Fintech. These developments are indicative of maturing economies and support strong economic growth ${ }^{1}$. In addition, market developments have brought benefits, particularly for SMEs and financial consumers through greater financial inclusion.

However, the growth of capital markets and shift in financial sector dynamics has also contributed to rising underlying risks. Key concerns relate to increasing levels of indebtedness combined with high leverage, maturity and liquidity transformation in a context of a weakening economic environment which may complicate the path of debt sustainability. Potential risks may also crystallise with an increase in losses due to higher corporate defaults that would erode the resilience of debtholders. The growing importance of market-based finance, while offering ample opportunities for additional funding sources and risk management, may also give rise to the potential risk of unexpected losses. The resulting tight and increasing financial sector linkages further raise concerns regarding systemic risk. In the event that these developments are not well monitored and managed, they could pose a risk to financial stability, as well as cause spillovers and amplify stress in the financial sector and real economy.

This paper will outline key developments in advanced and emerging Asian economies since the global financial crisis - focusing on market intermediation of sovereign and corporate debt, equity market development, as well as growth of alternative finance and structured products. In doing this, the paper will offer a forward-looking assessment to assess the extent to which medium-term developments can contribute to rising risks relating to the stability of financial intermediation and sustainable long-term growth. The objective is to inform policy discussions on economic opportunities but also of the underlying risk concerns.

The paper covers four major developments in the post crisis era and potential underlying risks. The first section looks at sovereign debt markets to compare sovereign debt levels in Asian economies to global trends and discuss underlying risks. Since the global financial crisis in 2008 , global debt has continued to rise reaching historic levels in recent years. Accommodative monetary policies, including unprecedented purchases of sovereign, corporate and household debt by major central banks, contributed to incentivize this growth and very low financing rates. However, risks are rising due to deteriorating fiscal positions in some countries that may worsen the efficacy of additional fiscal stimulus and the depth and duration of the current downturn. Also, debt rollover risk may increase under tighter monetary and financial conditions. Challenges in public debt management may also arise as a result of ambitious infrastructure development projects in the region.

The second section focuses on the rapid growth of emerging Asian non-financial corporate debt. Asian corporate bond markets have grown significantly over the last two decades. The expansion of these markets has been underpinned by strong economic growth and regulatory initiatives that have helped to improve market infrastructure and encourage greater market participation ${ }^{2}$. These developments have 
helped corporations to diversify their funding and are likely to have played a role in supporting the economies in the region during the global financial crisis. However, non-financial corporate debt issuers are facing rising leverage to cash flows and debt rollover risk with maturing debt. In the context of worsening global economic prospects, notably following the Covid-19 outbreak, this may erode the debt sustainability of many issuers and trigger rating downgrades and defaults that will further contribute to negative market dynamics.

The third section describes and provides analysis on the shift toward market-based finance that coincides with the rise in debt. The share of the financial sector in the overall economy has significantly increased in most emerging Asian economies in the post global financial crisis era, with a rapid growth of innovative finance. On an international scale, The People's Republic of China (hereinafter referred to as China) is by far the largest contributor to the expansion of such non-bank finance, while the size of China shadow banking has shrunk by half from 2017 to 2019 . While offering ample opportunities for additional funding sources and risk management, market-based finance may also give rise to potential risk of unexpected losses. Therefore, concerns are rising about potential spillover effects to other markets or financial intermediaries as firms offering market-based finance are not subject to the same level of stringent monitoring and regulation as banks, insurance companies or pension funds. In particular, FinTech could pose growing risks to financial intermediation if the regulatory environment fails to appropriately guide future developments and mitigate regulatory arbitrage in some parts of the system.

The fourth section examines the expansion of Asian equity markets. On an international scale, the most important development over the past 20 years has been the rapid growth of Asian stock markets ${ }^{3}$. Stronger equity markets in Asia could overcome some funding constraints stemming from strong reliance on bank financing and provide for a better risk transfer and risk sharing among market participants. The expansion of Asian equity markets may also help to partially mitigate corporate debt sustainability and rollover risk challenges. A favourable development in equity markets seems therefore key in providing the necessary support to sustainable economic growth in the region. The expansion of equity markets should also be analysed in light of the orientation of financial intermediation because more oriented debt financing rather than equity would raise potential debt sustainability concerns in the context of rising levels of indebtedness, leverage and deteriorating earnings.

Section five includes a summary of key findings, some concluding remarks and policy recommendations. 


\section{Debt markets}

Addressing the global financial crisis has required fiscal intervention on a substantial scale by governments around the world. The subsequent build-up of public debt, and its sustainability, has become centre stage in the policy debate. If the Asia region is to continue to serve as an engine for global growth, its public debt must be sustainable.

Since the global financial crisis, total global debt (including households, non-financial corporates, and general government) has continued to rise, growing by one-quarter from USD 137 trillion in 2007 to USD 186 trillion in 2018, resulting from strong increases in sovereign and corporate debt. Global sovereign debt rose from a $65 \%$ share of GDP in 2008 to a peak of $85 \%$ in 2017, and remains elevated (Figure 2.1). Accommodative monetary policies, including unprecedented purchases of sovereign, corporate and household debt by major central banks, contributed to incentivize this growth and very low financing rates.

\section{Figure 2.1. Sovereign and non-financial sector total outstanding debt, 2000-2019}

\section{General government $\quad \diamond \quad$ Total loans and bonds of the nonfinancial sector $\quad$ General govemment (\% of GDP}

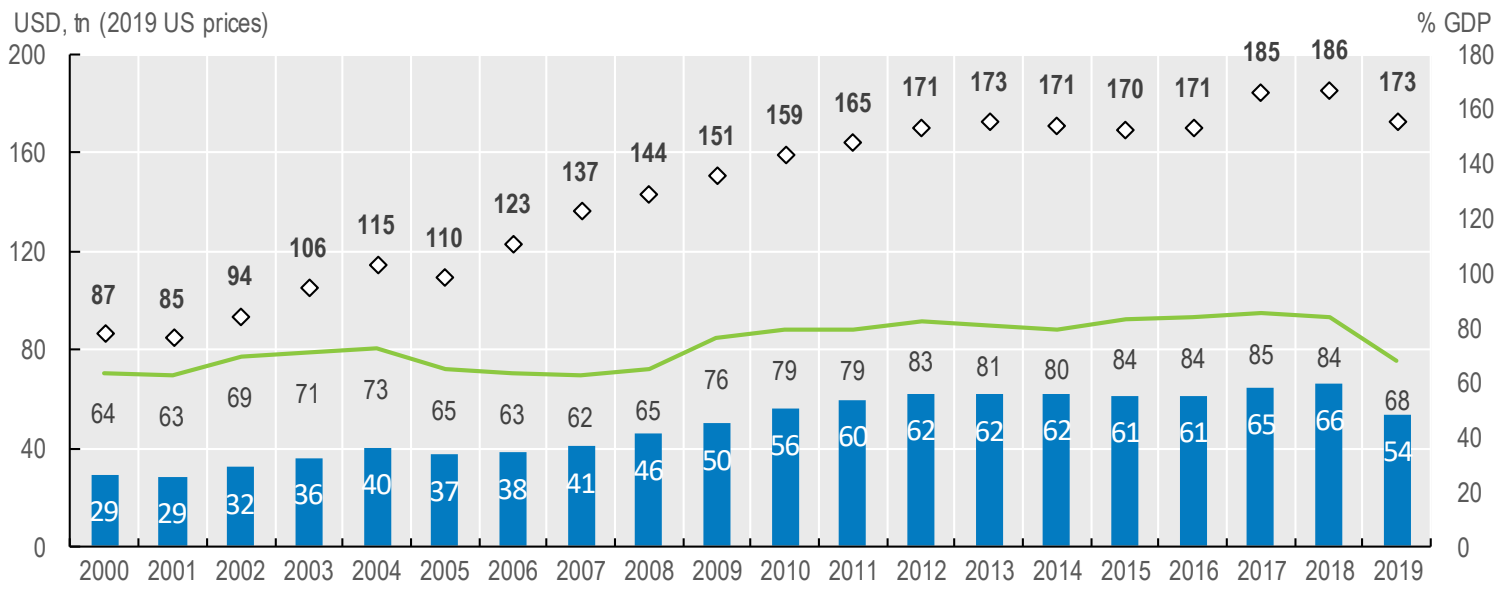

Note: The financial instruments covered comprise currency and deposits (which are mostly zero in the case of credit to the private non-financial sector), loans and debt securities. The sum of these three instruments is defined here as "core debt". For the government sector, core debt generally represents the bulk of total debt. Debt data for 63 countries are used in this chart. Outstanding amounts are presented in 2019 USD adjusted by US CPI.

Source: Bank of International Settlements, Credit to the non-financial sector database, IMF World Economic Outlook Database, OECD calculations

\subsection{Sovereign debt}

Asian economies exhibit moderate sovereign debt-to-GDP ratios compared to the global trend. Debt-toGDP ratios are below $100 \%$ for most Asian economies in 2019, except Japan, with a ratio exceeding a historically high $200 \%$. However, most Asian economies are facing notable increases in sovereign debt- 
to-GDP ratios over the post crisis period combined with deteriorating government deficit-to-GDP ratio (except Sri Lanka and Japan), particularly in China (Figure 2.2).

\section{Figure 2.2. Sovereign debt and budget deficit to GDP for selected Asian economies, 2007 versus 2019}
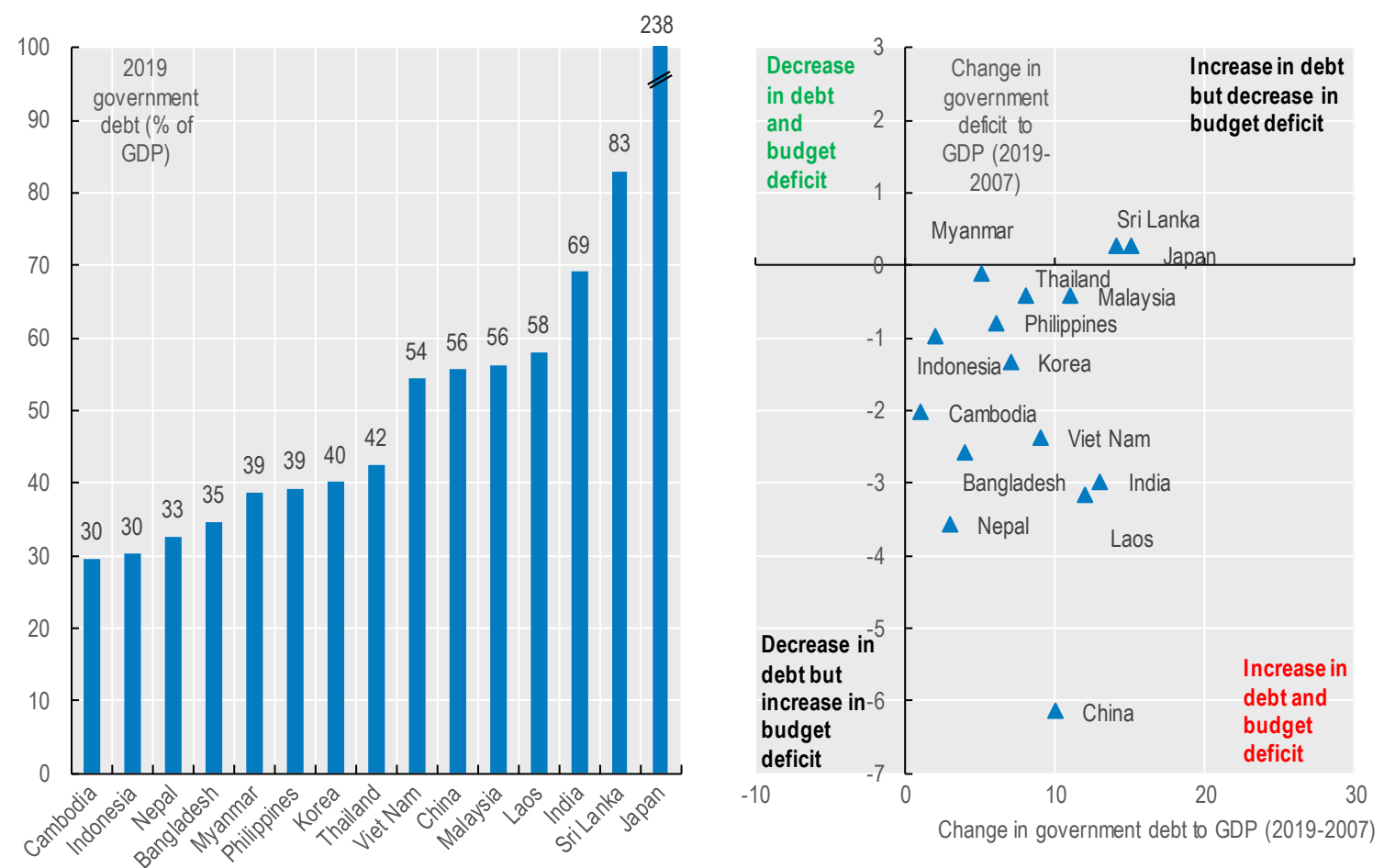

Source: IMF World Economic Outlook database, OECD calculations.

Rising sovereign debt-to-GDP ratios in the context of deteriorating public finance can complicate the path of debt sustainability ${ }^{4}$. This is particularly the case in light of slowing global economic growth following the Covid-19 outbreak, especially as additional fiscal stimulus may be called upon in a number of advanced and emerging economies to support growth and adequate social safety nets. Relatively low sovereign debt in most Asian economies gives the region a greater buffer against a potential economic downturn, enabling policymakers to use expansionary fiscal policy to support demand. But deteriorating fiscal positions of several Asian economies (i.e. China, India, Laos and Viet Nam) may complicate the efficacy of additional fiscal stimulus during a protracted downturn. The resulting further deteriorated fiscal positions may have potential implications for sovereign debt sustainability.

Potential debt concerns in the region may also arise from China's Belt and Road Initiative which is responding to major infrastructure gaps in Asia and boosting economic growth and global trade. However, the increase in public debt to finance infrastructure projects may be potentially concerning if it limits other spending as debt service rises, and creating balance of payment challenges. Estimates by the Asian Development Bank (ADB, 2017) point to investment needs in the Asia region of around USD 26 trillion until 2030 (including climate-related needs). The highest investment needs, in percent of GDP, within the region are seen in the Pacific (9.1\%) as well as in South (8.8\%) and Central Asia (7.8\%). This compares to around $5.7 \%$ in Southeast Asia and 5.2\% of GDP in East Asian economies ${ }^{5}$. These factors raise concerns about the impact of very accommodative monetary and fiscal policies on the level of debt, and the influence of exuberant pricing of market assets on the sustainability of asset valuations. In Asian countries where public debt-to-GDP ratio is increasing, careful management of financing terms is critical. China and partner 
governments are implementing strategies that seek to mitigate these potential risks to maintain macroeconomic stability and debt sustainability ${ }^{6}$.

\section{Figure 2.3. Amount of local currency sovereign debt with a maturity less than 5 years for selected} Asian economies, 2007 versus 2019

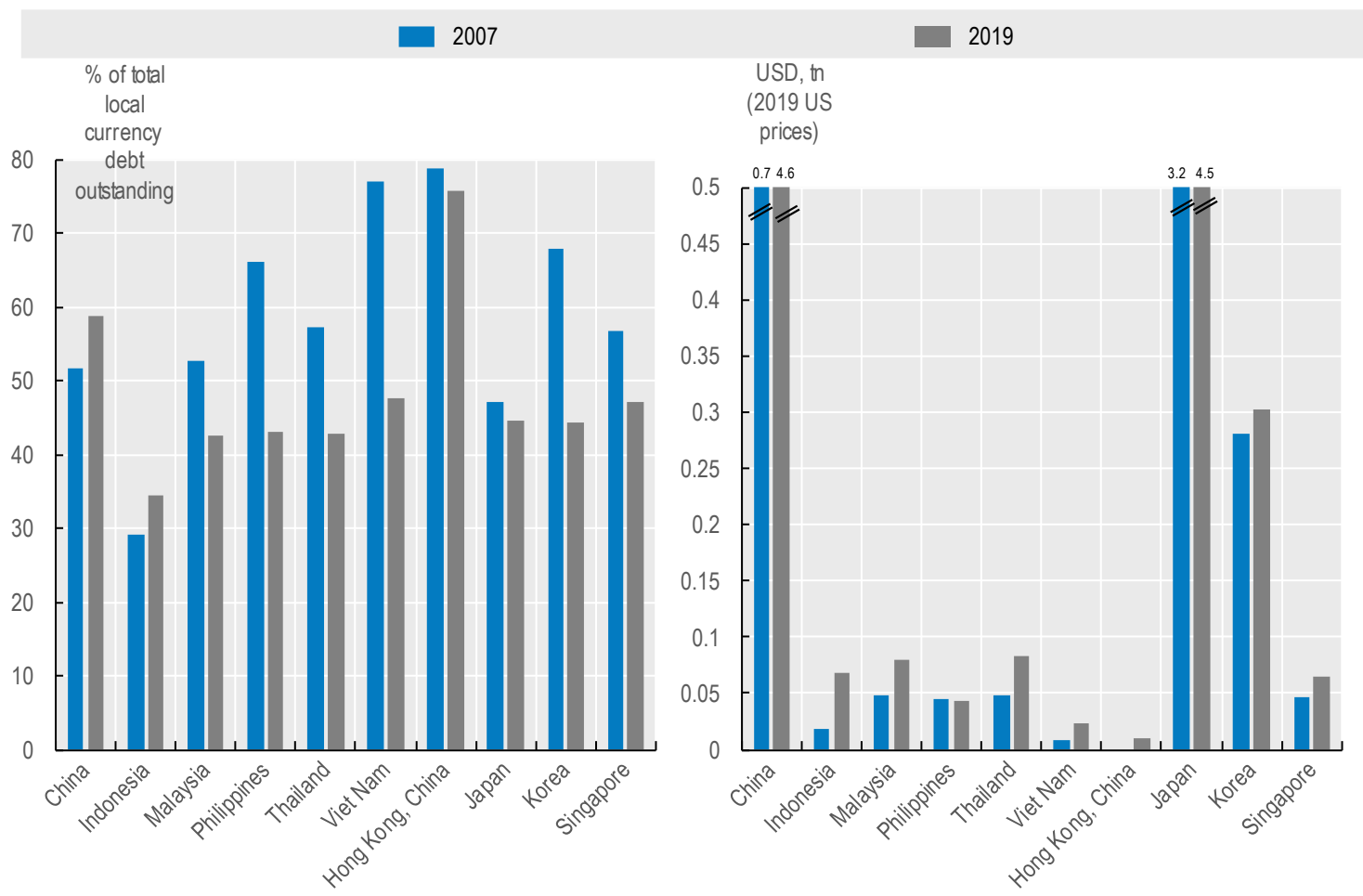

Note: This indicator classifies government bonds by remaining time to maturity. Government bonds include central government, local governments, central bank bonds, and state-owned enterprises with remaining maturities less than 5 years. The maturity profile is presented as a percentage of total local currency debt outstanding in $<1-3$ and 3-5 year maturity buckets. The outstanding amount local currency debt outstanding in <1-3 and 3-5 year maturity buckets is also presented in 2019 USD adjusted by US CPI.

Source: AsianBondsOnline, OECD calculations.

In light of growing risks, Asian governments like many other sovereign borrowers globally have taken the opportunity in this low-rate environment to extend their maturity schedule to reduce the amount of debt that needs to be refinanced over the next years. Over the period 2007-2019, the share of local currency debt maturing in less than 5 years in total local currency debt outstanding has risen significantly in China and Indonesia but has decreased in most Asian economies, particularly in Viet Nam, Korea and Philippines. In absolute terms, China has experienced the most notable increase with an additional USD 3.9 trillion from 2007 to 2019, and to a lesser extent Japan with an additional USD 1.3 trillion. In 2019, these two countries exhibited the highest levels of debt maturing in less than 5 years among selected Asian economies (Figure 2.3). The negative impact of the Covid-19 outbreak on economic growth and public finance may lead market participants to require substantially higher risk premia. Therefore, the cost of new debt issuance will depend upon funding needs, the rate differential relative to debt maturing and the extent to which the debt was hedged by debt agencies. Debt rollover risk is limited for most Asian governments with relatively low levels of debt and long-term maturities. However, for countries with relatively high levels of debt (especially China), a rollover of debt at even moderately higher funding costs would stretch fiscal deficits. 


\subsection{Corporate debt}

Since the global financial crisis, Asian corporates have made increasing use of bond issuance for their funding needs, complementing traditional channels such as bank lending. Throughout the region, bankintermediated credit remains the dominant source of financing for companies. Bank-based financial intermediation has a traditionally strong position in Asia, where it can draw on the region's sizeable pool of domestic savings. In Indonesia, Malaysia, Thailand and India, for instance, banks depend on retail deposits for more than $75 \%$ of their funding ${ }^{7}$. Relationship-based lending continues to play a central role in Asia, especially where the corporate sector is to a significant extent shaped by family-controlled conglomerates. However, the dominant position of bank credit is increasingly being challenged. Firms' attempts to tap funding sources outside the bank channel have received fresh impetus due to a number of factors in recent years.

Figure 2.4. Corporate bonds outstanding globally, 1997-2019

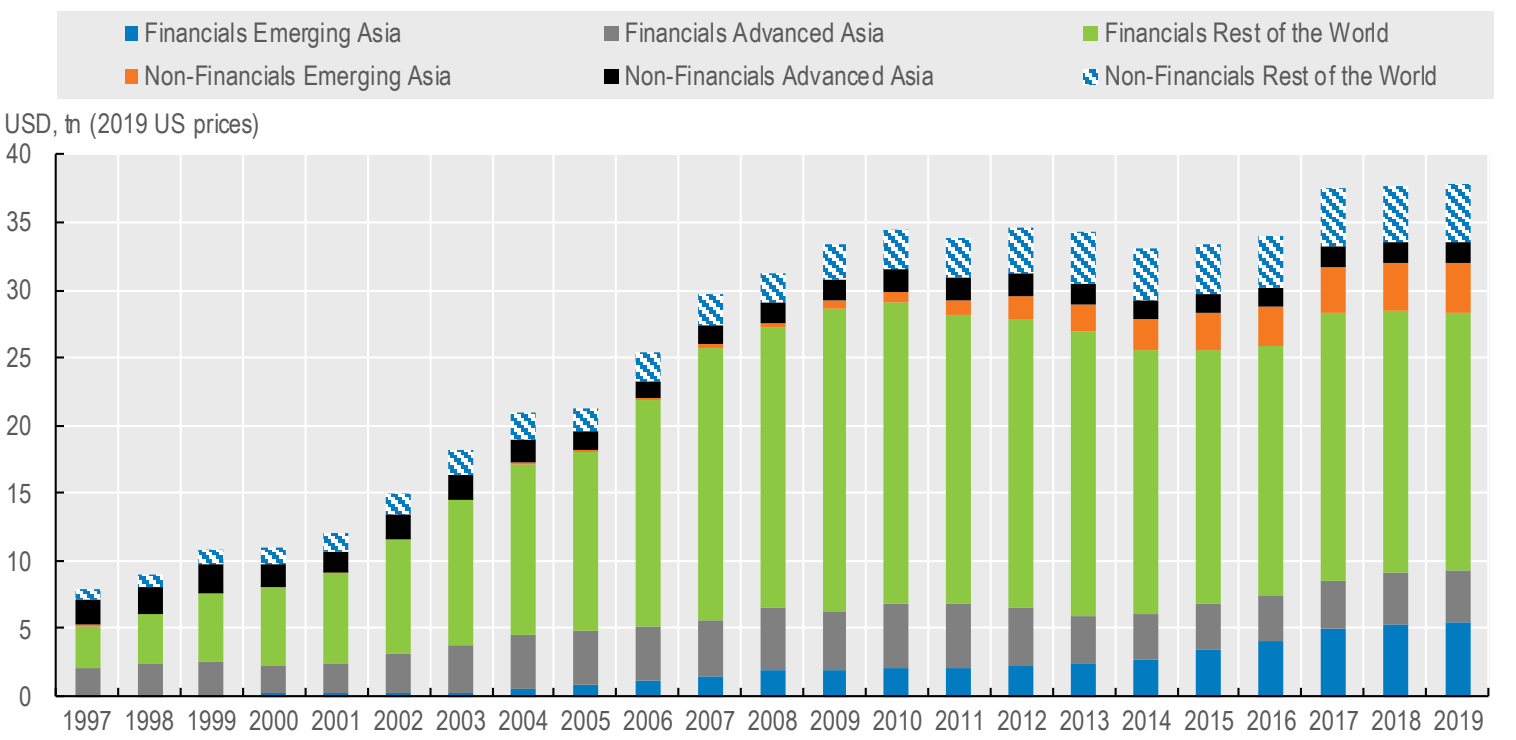

Note: This indicator shows the total outstanding amount of corporate bonds issued by financial and non-financial companies globally on domestic and international markets. Outstanding amounts are presented in 2019 USD adjusted by US CPI.

Source: Bank of International Settlements, Debt securities statistics, OECD calculations.

In the aftermath of the global financial crisis, the outstanding amount of global corporate bonds (including financial and non-financial companies) has continued to rise reaching USD 38 trillion in 2019 illustrating sharp growth from USD 15 trillion in 2002 (Figure 2.4). Over the period 2002-2019, corporate bond outstanding in the Asia region also surged: the outstanding amount of emerging Asian financial corporate bonds accounted for $2 \%$ of the global financial corporate bond outstanding amount in 2002 while the share has increased to $20 \%$ in 2019 . The most important development has been the rapid growth of emerging Asian non-financial corporate debt. Over the period 2002-2019, the outstanding amount of emerging Asian non-financial corporate bonds grew from 1.2\% to $40 \%$. Given the increasing size of Asian non-financial corporate debt, the evolution of Asian corporate debt markets will have important global implications.

Corporate bond issuances have continuously increased since 2005 leading the corporate debt outstanding-to-GDP ratio to rise from $14 \%$ of GDP in 2008 to $29 \%$ in 2019 . In the meantime, domestic bank lending as a share of GDP has also grown from $157 \%$ in 2008 to $221 \%$ in 2019 . While corporate bond markets have expanded since the global financial crisis but bank financing in Asian economies remains dominant (Figure 2.5). 
Figure 2.5. Nominal corporate debt issuance and outstanding debt-to-GDP for selected Asian economies, 2002-2019

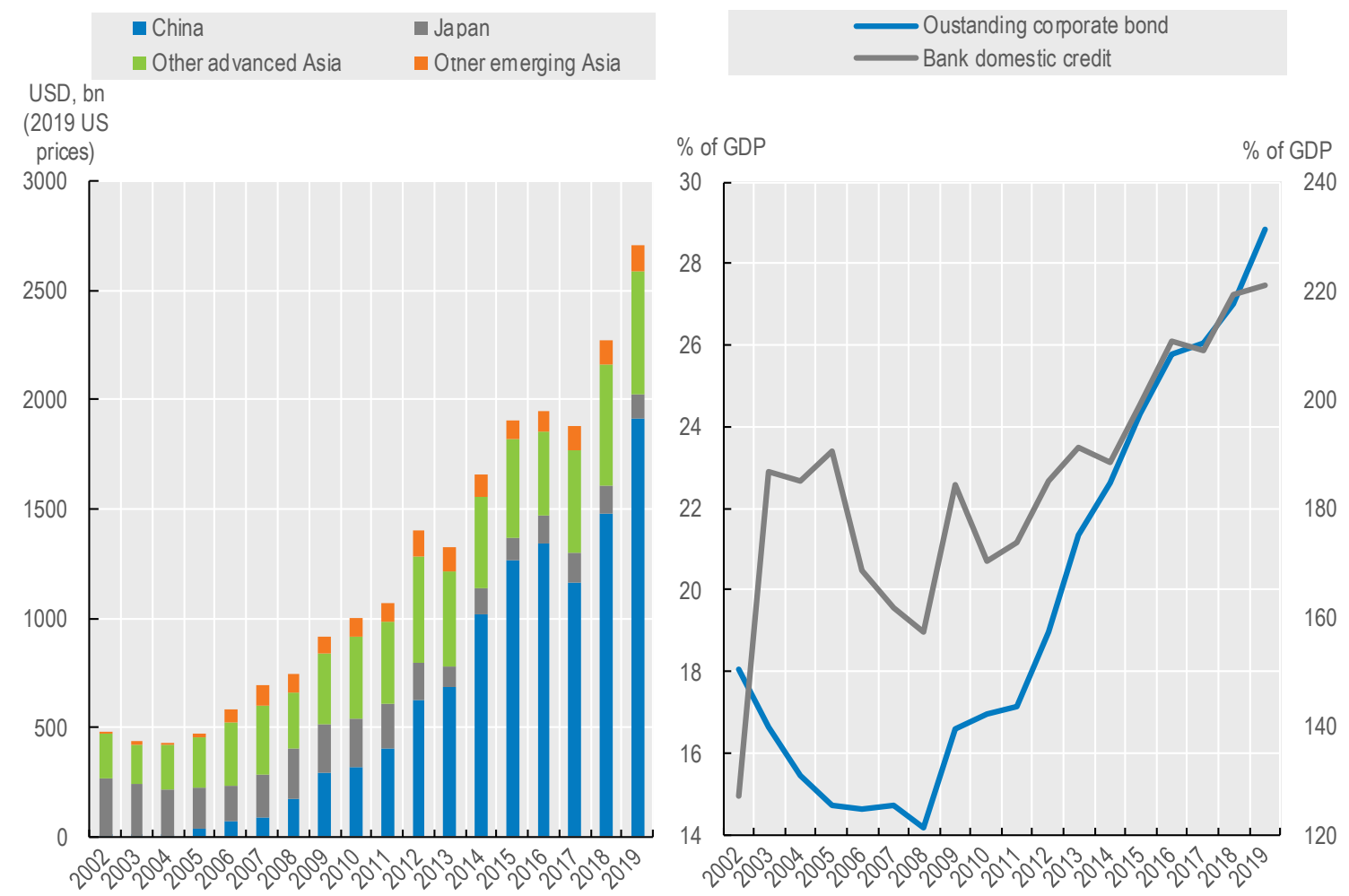

Note: This indicator shows the total volume of local currency (LCY) corporate bond issuance. Corporate bond issuance includes bonds issued by both public and private companies, and financial institutions. Issuance amounts are presented in 2019 USD adjusted by US CPI.

Source: AsiaBondsOnline, Asian Development Bank Financial Sector Development Dataset, IMF World Economic Outlook Database, OECD calculations.

A closer look at corporate bond issuances in Asia shows that China is by far the largest contributor to issuance growth. ${ }^{8}$ China has moved from negligible issuance levels prior to the crisis to a record issuance amount of USD 1.9 trillion in 2019. At end-2019, about $80 \%$ of total corporate debt has been issued in local currency. This generally indicated that Chinese companies are raising funds to finance local investment projects.

Concerns are arising that continued growth in debt issuance combined with high leverage, should it continue, would make the region's financial systems more fragile to an exogenous shock, such as from pandemics. Non-financial corporate debt issuers are highly leveraged to cash flows in most Asian economies compared to other regions over the period 2002-2019. Other advanced and emerging Asian economies exhibit the highest ratios of total debt to EBITDA in 2019 followed by United States, China, India, Japan, and Europe (Figure 2.6). Worsening global growth prospects following the Covid-19 outbreak is likely to erode the debt sustainability of some leveraged issuers, and could contribute to a sharp rise in defaults as the credit cycle turns. Such pressures and ratings movements, in turn, would cause investors to demand a higher credit risk premia, potentially exacerbating debt financing costs for non-financial corporates in some of these economies. As documented by Fitch Rating (2020), corporate default risk is rising in China, notably for state owned enterprises (SOEs) ${ }^{9}$. Fitch Rating analysis suggests that while default risks vary across economic sectors, the majority of cases are in commercialised sectors, many of which suffered from oversupply. Also, firms engaged in sectors of strategic or policy importance appear less likely to go into financial distress. Therefore, Chinese SOEs are likely to face adverse conditions in 
the current economic context, and the firms operating in commercialised sectors would be the most exposed. In fact, growth sensitive sectors are the most affected by the Covid-19 outbreak ${ }^{10}$.

\section{Figure 2.6. Non-financial listed companies' debt to EBITDA ratio for selected economies, 2004-2019}

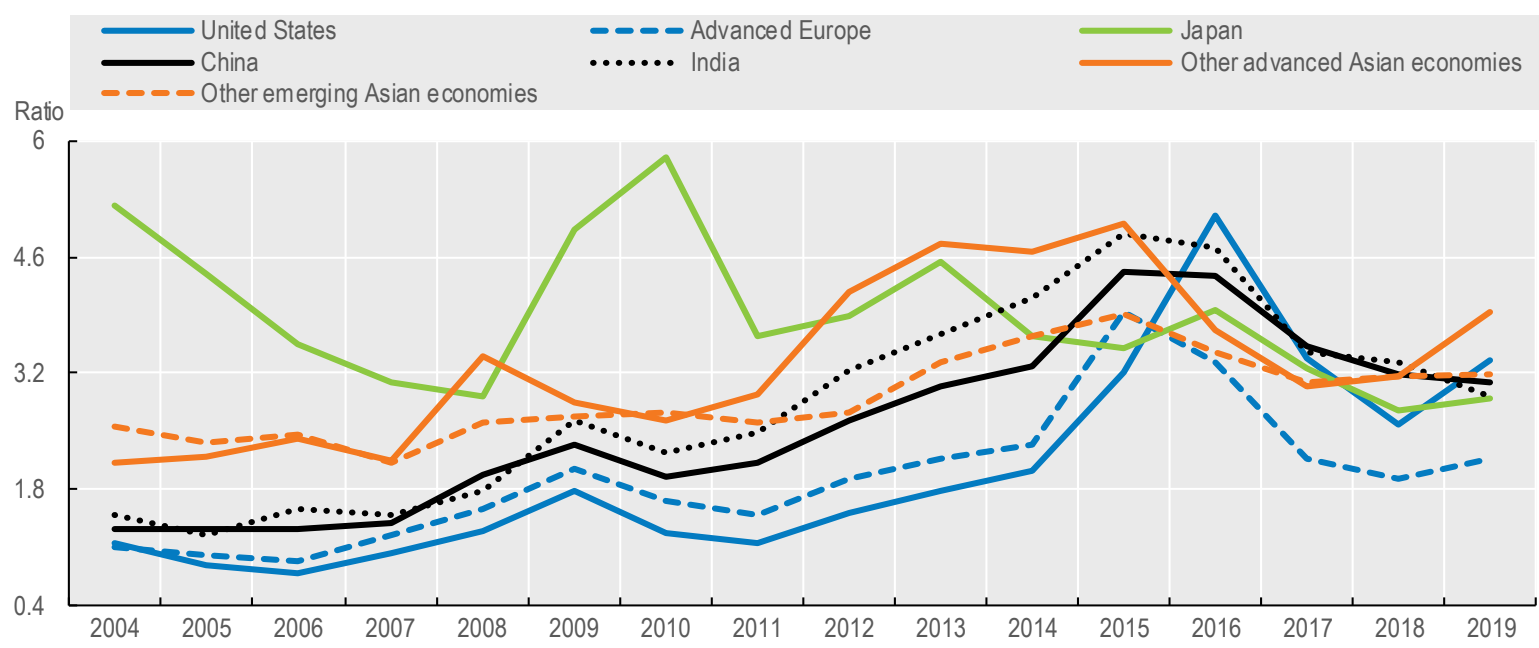

Note: EBITDA represents income before interest, taxes, depreciation and amortisation. Total debt includes loans and short and long term bonds. Leverage calculations are performed using a global sample of 12,220 listed non-financial companies with available financial statement data in Refinitiv over the period 2004-2019. Annual consolidated financial statements are collected on an annual basis, at the firm level and in current USD. All data are trimmed at the $1^{\text {st }}$ and $99^{\text {th }}$ percentile levels to reduce the effect of outliers.

Source: Refinitiv, OECD calculations.

A continuation of the recent upward trend of corporate defaults and losses would erode the resilience of debtholders, including banks, finance companies, asset managers, insurance and pension funds. Depending on their risk management frameworks, these institutions would face pressures to reduce credit exposures through costly hedging and portfolio rebalancing, which would further contribute to widening spreads and imbalances in market liquidity (Figure 2.7). Notably, the Asia Pacific high-yield corporate bond option adjusted spread has risen sharply as a result of the Covid-19 outbreak. This sharp widening in credit spreads reflects investors' concerns about worsening earnings prospects that may trigger rating downgrades and debt sustainability issues, particularly in large Asian emerging market economies. As documented by Moody's (2020), the trailing 12-month default rate of high-yield corporates in the region is expected to rise to $6.4 \%$ at the end of 2020 , which is materially higher than the $1.1 \%$ default rate in 2019 . The surge in the baseline default rate forecast reflects the expectation of a global economic recession amid Covid-19 disruptions. These disruptions have led to simultaneous supply and demand shocks in the past few months and put pressure on companies' earnings, while recovery is expected to be tepid even if economic activity resumes in the second quarter. Companies' operating performance will continue to be under pressure, resulting in further weakening of the credit quality of some Asian companies. The difficult macroeconomic environment increases the default risk of companies with weak business fundamentals and/or high leverage as well as the likelihood of distressed exchanges. In a pessimistic scenario, in which it is assumed that Covid-19 will create wider and deeper economic disruptions throughout the year, the Asia-Pacific high-yield corporate default rate will reach $9.1 \%$, compared with the peak of $14.1 \%$ at the end of $2009^{11}$. 
Figure 2.7. Speculative grade corporate defaults, 1994-2018

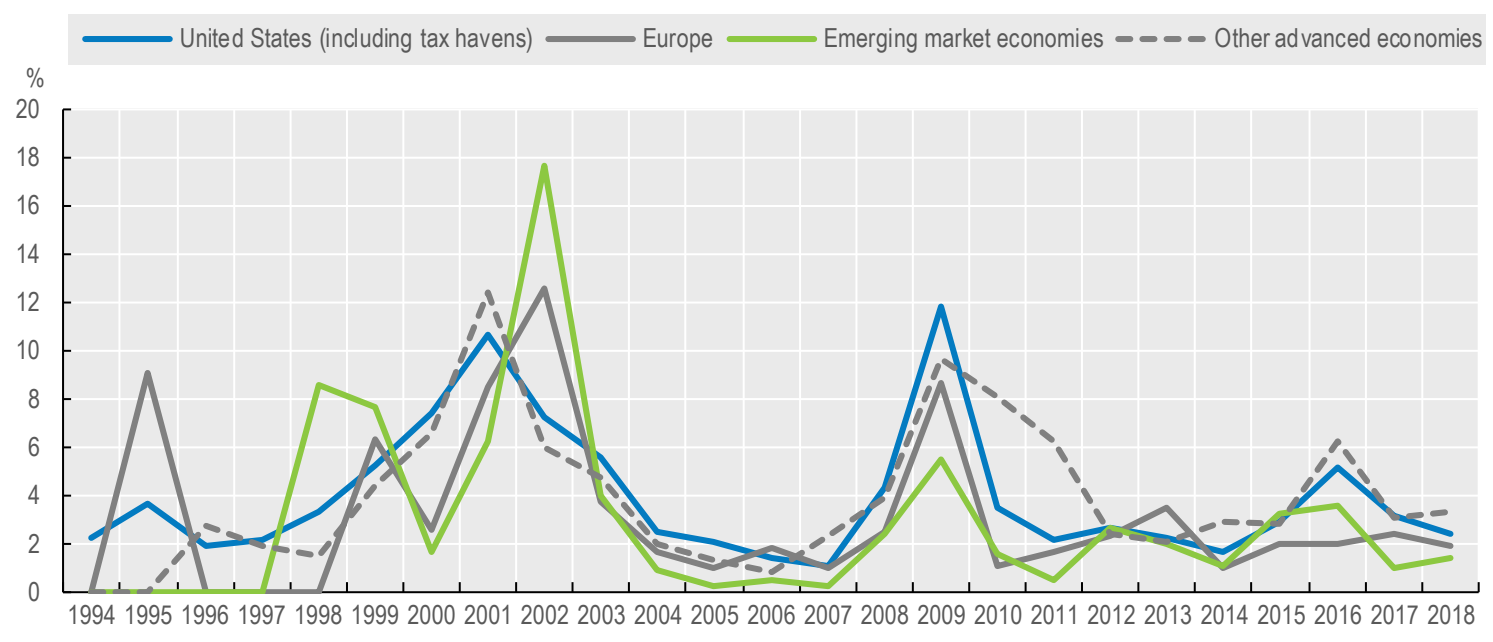

Source: S\&P Global Ratings, 2018 Annual Global Default Study and Rating Transitions.

The economic impact of the Covid-19 outbreak is contributing to a sharp erosion of corporate performance in many Asian firms, which in turn questions debt sustainability of some leveraged issuers, that may lead market participants to require substantially higher risk premia. Therefore, examining the maturity profile may prove useful to understand the speed with which a rise in credit risk premia will be reflected in the cost of new issuance depending upon funding needs. Over the period 2007-2018, the share of debt maturing in less than 5 years in total debt outstanding has risen significantly in China, Viet Nam and Indonesia. In absolute terms, China has experienced the largest increase followed by Philippines and Korea (Figure 2.8). Debt rollover risk is limited for economies with relatively low levels of debt issuance and long-term outstanding debt maturities. However, for jurisdictions with relatively high levels of corporate debt issuance and leverage, especially China, a rollover of debt at even moderate increases in financing cost could push credit risk premia on corporate debt higher, and trigger downgrades, further contributing to negative market dynamics. 
Figure 2.8. Amount of local currency corporate debt with a maturity less than 5 years for selected Asian economies, 2007-2018

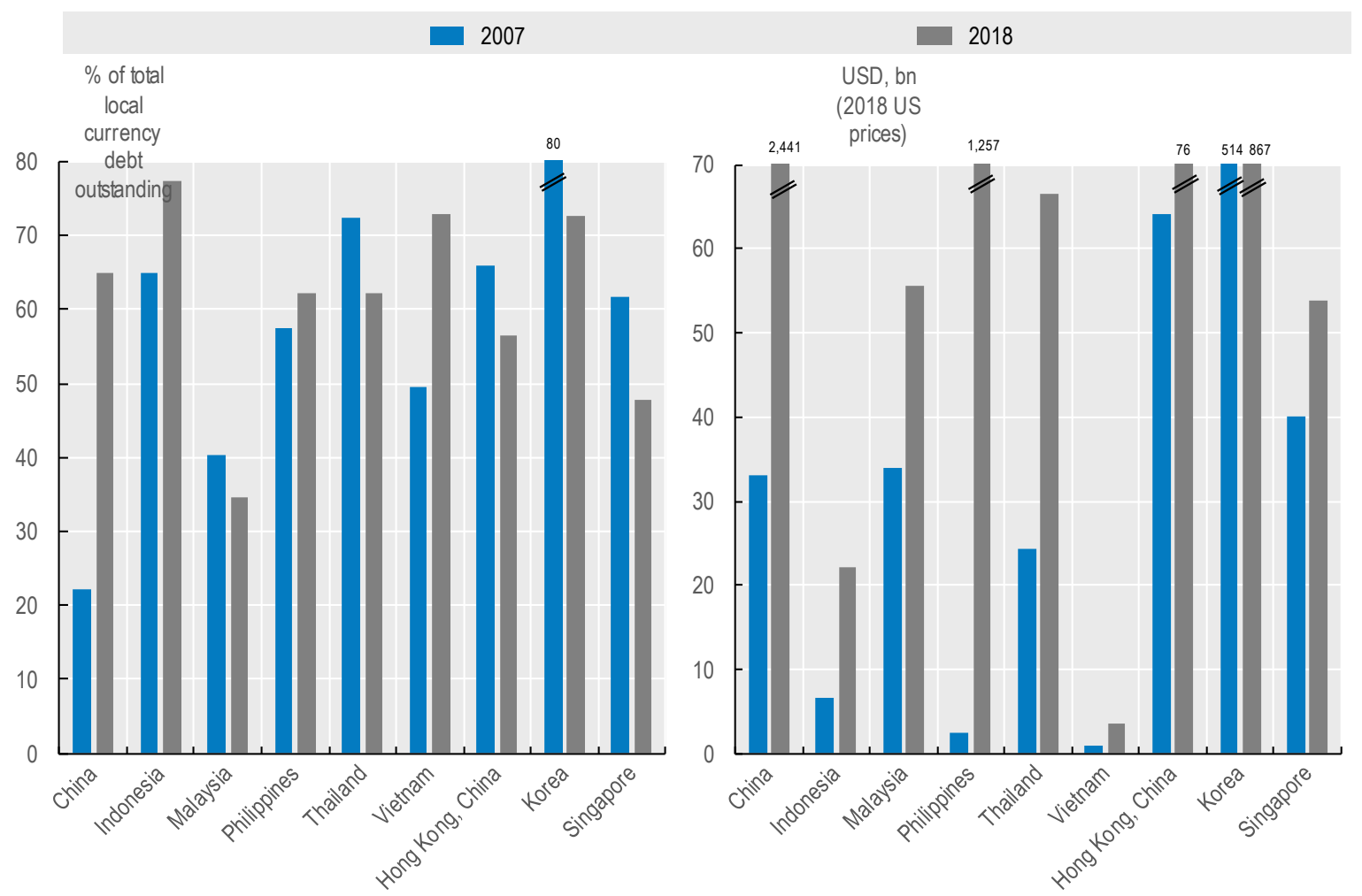

Note: This indicator classifies corporate bonds by the remaining time to maturity. Corporate bonds comprise both public and private companies, including financial institutions, with remaining maturities less than 5 years. The maturity profile is presented as a percentage of total corporate bonds outstanding in $<1-3$ and 3-5 year maturity buckets. The outstanding amount local currency debt outstanding in $<1-3$ and $3-5$ year maturity buckets is also presented in 2018 USD adjusted by US CPI.

Source: AsiaBondsOnline, OECD calculations. 


\section{Market-based finance and Fintech credit in Asia}

\subsection{The rise of market-based finance}

Over the period 2007-2018 ("the period"), the size of financial sectors relative to the economies in which they operate have significantly increased in most countries around the world. The largest increase of the share of financial sector assets (excluding central bank assets) to GDP was in Europe, followed by emerging economies (excluding emerging Asian economies) and the Asia region. In contrast, the share of financial sector assets in GDP has slightly increased in the United States, although the shift in types of market-based finance has been remarkable. In levels, the size of the financial sector in the overall economy is by far the largest in Europe, followed by the United States and Asia. The size of the financial sector in the overall economy in emerging economies (excluding emerging Asian economies) is relatively small compared to the other selected economies (Figure 3.1).

Figure 3.1. The relative size of the financial sector in selected economies, 2007-2018

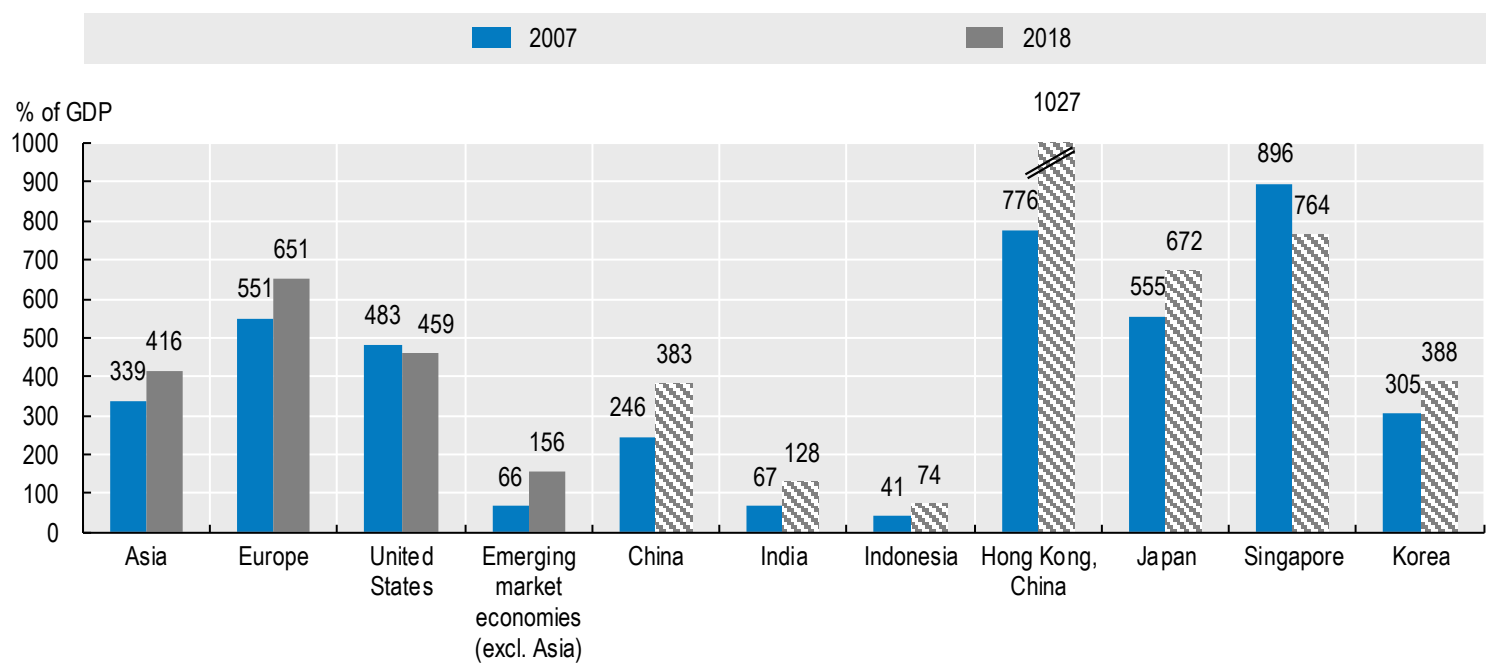

Note: National sector balance sheet data for 47 countries are used in this chart. Asia includes China, Hong Kong, China, India, Indonesia, Japan, Korea and Singapore. Europe refers to European Union, Iceland, Norway and Switzerland. Emerging economies excluding Asian economies includes Argentina, Brazil, Chile, Colombia, Hungary, Mexico, Poland, Russia, Saudi Arabia, South Africa and Turkey.

Source: Financial Stability Board 2019 Global Monitoring Report on Non-Bank Financial Intermediation, OECD Financial Account database, OECD calculations.

Focusing on the Asia region, the share of financial sector assets to GDP has increased the most in Hong Kong, China, followed by China, and Korea. It has also grown but to a lesser extent in Japan, India and Indonesia. However, share of financial sector assets in GDP has decreased in Singapore. In levels, the 
size of the financial sector in the overall economy in several selected Asian economies largely exceeds the size in other regions with well-established financial centres such as the United States and Europe. Mainly Singapore, Hong Kong, China and Japan exhibit high financial sector assets-to-GDP ratios, followed by Korea and China (Figure 3.1). ${ }^{1}$

On an international scale, over the last decade, the structure of the financial sector has undergone profound changes with the rise of market-based finance. While evidence is mixed, this shift has been attributed in part to the arbitrage of post-crisis regulatory reforms. As noted by the Financial Stability Board (2017a), "a series of measures are eliminating toxic forms of shadow banking and transforming the remaining into resilient market-based finance". Many potential benefits are associated with the rise of market-based finance (BOE, 2017) to reduce financial stability risks, such as the benefit of portfolio diversification and also diversity for individual investors. Market-based finance is more able to share risk and pass losses back to investors than the banking system. Also, investment funds do not carry the same solvency risks as banks as investors are entitled only to the market value of their investments. In a crisis, the valuation of the assets and of the redeemable equity of investment funds broadly move in the same direction, whereas for banks, assets can go down in value while the liabilities remain fixed - banks being highly leveraged.

Some notable shifts have occurred in Europe, the United States and the Asia region while the structure of the financial sector has remained stable in other non-Asian emerging economies (Figure 3.2). In Europe, bank financing remains quite large although bank assets have moderately declined to $42 \%$ of total financial sector assets. In contrast, a sharp rise to $42 \%$ of the share of investment funds and other financial intermediaries is notable, driven by the rising size of non-money market funds (MMFs). In the United States, the share of bank assets has remained low and stable at $20 \%$ of financial sector assets (excluding the central bank) while the share of investment funds and other financial intermediaries has substantially decreased from $51 \%$ to $45 \%$. However, this drop of the share of investment funds and other financial intermediaries in the United States is due to a sharp drop in MMFs offset by strong growth of non moneymarket investment funds. Both in the United States and in Europe, the fall in the share of banks relates to the slowdown in bank lending and to a certain degree, in balance-sheet deleveraging in Europe over the post global financial crisis period.

Regulatory reforms and higher capital and liquidity constraints on large banks following the global financial crisis may have also contributed to a shift of lending to market-based finance where the application of macro-prudential tools is more limited. Finally, in the Asia region, the share of bank assets has remained quite large and stable at around $60 \%$ of financial sector assets (excluding the central bank) while the share of investment funds and other financial intermediaries in financial sector assets has modestly expanded from $23 \%$ to $28 \%$. Like in the United States and Europe, the share of non-MMF assets in overall fund assets has increased in Japan. Following the global financial crisis, major collapse of asset-backed securities markets and the low interest rate environment with expansionary monetary policies around the world, led investors searching for yield and they became willing to transition from low-yielding MMFs to higher-risk investment funds that provide higher yield, such as corporate bonds, leveraged loans, and bank contingent convertible ( $\mathrm{CoCo}$ ) bonds. Nearly a decade on from the onset of the global financial crisis, the significant rise of market-based finance, though offering benefits in product choice, diversification and risk management, also brings risks.

While financial sectors in Asia are heterogeneous, the prominent but decreasing share of banks in the overall financial sector is a common characteristic of most Asian economies over the period. The sharpest decreases in the share of banks' are in China, Korea, Singapore and India. However, Japan is the

\footnotetext{
${ }^{1}$ Considering the prominence of China and Hong Kong, China financial sectors within the Asia region, it is worth mentioning the deepening financial linkages between the two economies and the implications for markets and financial intermediaries of rising downside risks. Annex A focuses on the financial linkages between Mainland, China and Hong Kong, China through several channels and discusses the bilateral implications of rising downside risks.
} 
exception with a weaker (more similar to Europe level in 2007) and increasing share of banks in the overall Japanese financial sector. The share of banks' assets in financial sector assets (excluding the central bank) is varying in a range of $53 \%$ to $78 \%$ in selected Asian economies in 2018 , which is $37 \%$ in advanced economies and $62 \%$ in emerging economies.

Figure 3.2. The structure of the financial sector by categories of financial institutions in selected economies, 2007-2018

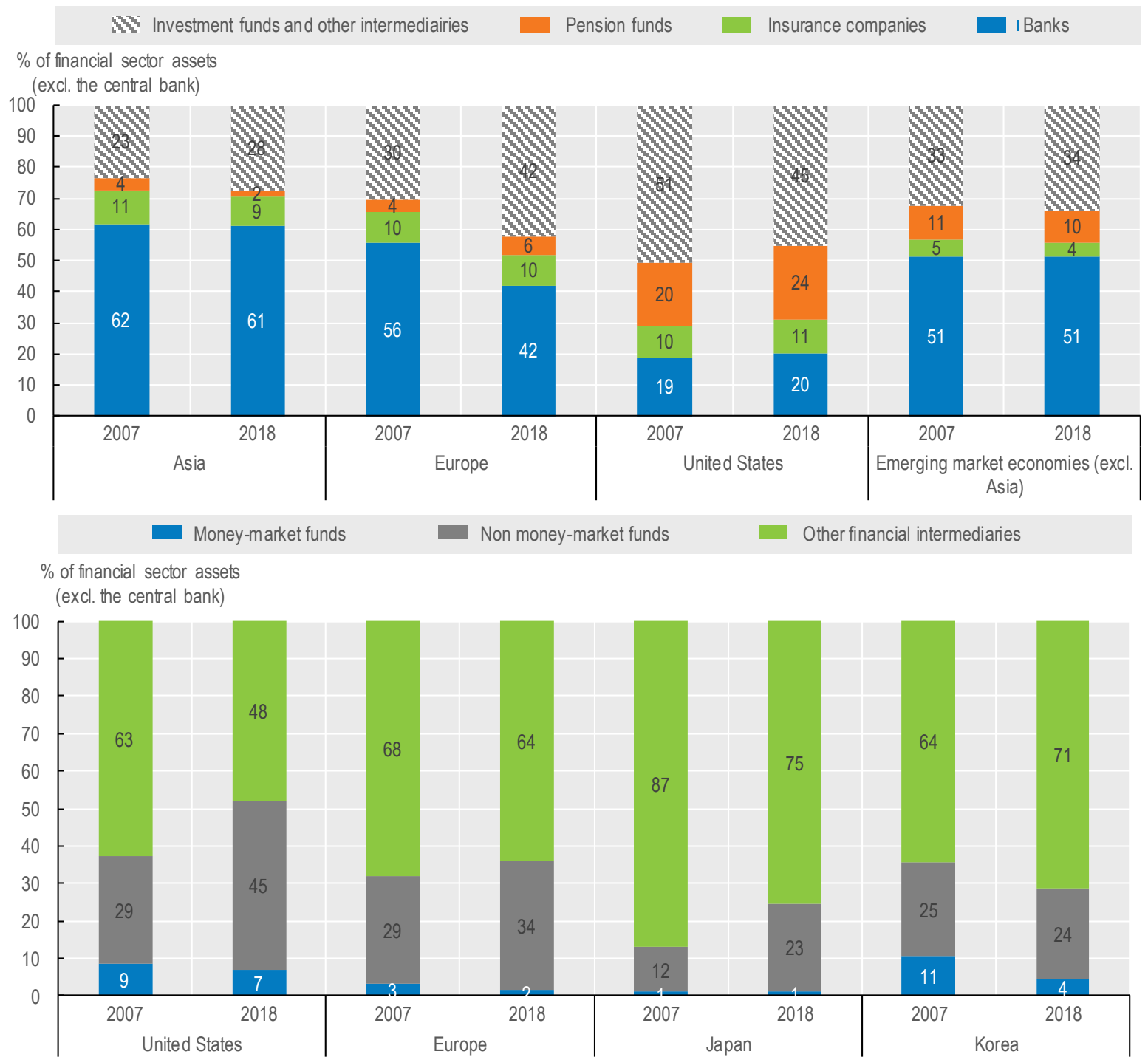

Note: National sector balance sheet data for 47 economies are used in this chart. Asia includes China, Hong Kong, China, India, Indonesia, Japan, Korea and Singapore. Europe refers to European Union, Iceland, Norway and Switzerland. Emerging economies excluding Asian economies includes Argentina, Brazil, Chile, Colombia, Hungary, Mexico, Poland, Russia, Saudi Arabia, South Africa and Turkey. This figure presents a detailed breakdown of the several components of the financial sector (excluding the central bank) with a focus on the several types of "investment funds and other intermediaries". The investments fund category includes money market funds, non-money market investment funds and other financial intermediaries.

Source: Financial Stability Board 2019 Global Monitoring Report on Non-Bank Financial Intermediation, OECD Financial Account database, OECD calculations. 
In parallel, the share of investment funds has strongly increased in these four economies, which have experienced a significant rise of market-based finance. The share of investment funds has expanded substantially in China and to a lesser extent in Singapore, India, and Korea. In levels, the size of investment funds in the financial sector is by far the largest in China, followed by Korea, Japan and India. Some other notable changes are the increase in the share of insurance companies in Korea and in Hong Kong, China (Figure 3.3). Risk concerns are rising with a significant increase in market-based finance around the world, notably liquidity risks over fixed-income investment funds and investor protection. Banks, insurance companies and pension funds are subject to stringent monitoring and regulation with binding capital rules and emergency fund requirements in case of unexpected failure in many countries around the world. Even if investment management firms are subject to strict operational standards and organisational requirements (such as conflicts of interest and conduct rules), liquidity and risk management strategies are less in the scope of the regulation. Investors are required to be well informed and aware of their risk exposure as the value of their assets is not backed by any emergency disposal in case of financial distress.

\section{Figure 3.3. The structure of the financial sector by categories of financial institutions in selected Asian economies, 2007-2018}

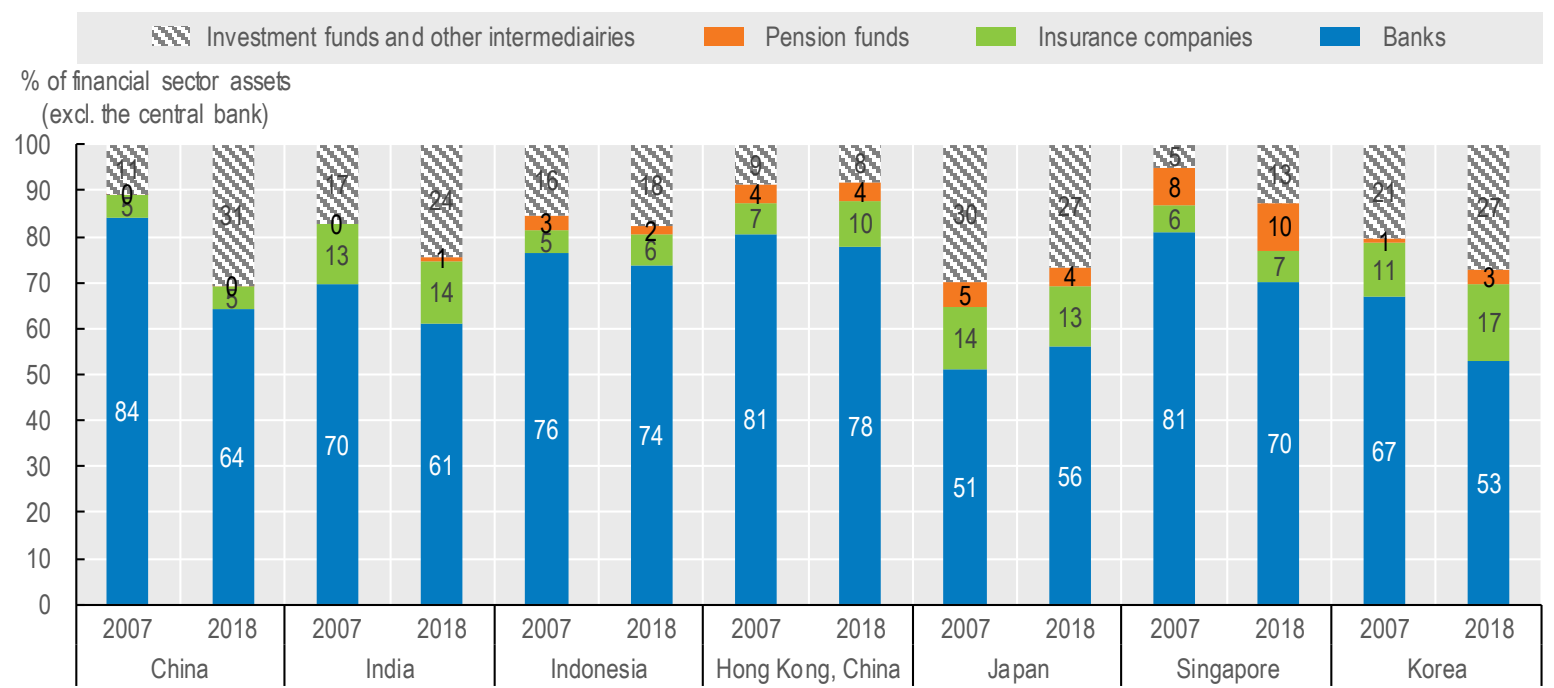

Note: National sector balance sheet data for 7 selected Asian economies are used in this chart. This figure presents a detailed breakdown of the several components of the financial sector (excluding the central bank). The "investment funds and other intermediaries" category includes money market funds, non-money market investment funds and other financial intermediaries.

Source: Financial Stability Board 2019 Global Monitoring Report on Non-Bank Financial Intermediation, OECD Financial Account database, OECD calculations.

\subsection{The increasing importance of non-bank credit intermediation}

Non-bank credit intermediation, commonly known as "shadow banking", can refer to entities, activities, or products. The Financial Stability Board (2011) broadly describes shadow banking as "credit intermediation involving entities and activities outside of the regular banking system" and offers a relatively narrow definition of "non-bank credit intermediation where shadow banking risks such as maturity transformation, liquidity transformation or leverage may occur". Non-banks are major players in shadow banking activities, although certain off-balance sheet activities by banks also fit the broad definition of shadow banking.

A closer look at non-bank credit intermediation activities in the Asia region shows that China is by far the largest contributor to the expansion of such alternative finance. Using Financial Stability Board (FSB) 
narrow measure of shadow banking ${ }^{12}$ scaled by financial sector assets (including the central bank) or GDP, China is ranked $8^{\text {th }}$ and $9^{\text {th }}$ among 29 selected economies respectively in 2018 . In absolute terms, the Chinese shadow banking sector is the world's second-largest in 2018 after the United States, with total assets of USD 7.8 trillion. In 2018, total assets of China's shadow banking sector accounts for about half of US shadow banking sector but is about 3 times more than in Japan or in Ireland and between 4 and 5 times more than in the United Kingdom, Germany or France (Figure 3.4).

Shadow banking in China takes a markedly different form compared to that in the United States ${ }^{13}$. A key characteristic is that commercial banks are the dominant players in China's shadow banking system. The rise of such new and complex "structured" non-bank credit intermediation has emerged and quickly reached a large scale driven by banks trying to alleviate regulatory burdens (i.e. non-performing loan provisions or loan to debt ratio ceilings) through a reclassification of existing bank assets into investment receivables. Most shadow financing in China includes undiscounted bankers' acceptances, trust and entrusted loans and wealth management products (WMPs). ${ }^{14}$ Companies are now able to lend to each other through three mechanisms that involve banks as intermediaries only, and to which reserve requirements and ceilings on interest rates and bank credit do not apply. First, with undiscounted bankers' acceptances, companies can issue a bill that instructs the bank to make payments to corporates and the bank acts as a guarantor (i.e. the acceptance liability replacing the money paid to the third party). This transaction is essentially a bank loan in economic form, but remains off the balance sheet of the bank unless the exposure becomes non-performing. Second, with trust and entrusted loans, the company can also engage in direct lending, with trust funds acting as the intermediary. Banks may be indirectly involved as administer of trust funds on behalf of individuals and entities and may provide credit facilities to such funds.

While the size of China shadow banking has shrunk by half from 2017 to 2019 , it remains elevated at $30 \%$ of GDP (Figure 3.5). Also, operating revenues of trust companies continue rising while their profits are slightly falling over the recent years. Investment and trust business incomes are increasing. With more complex credit products under regulatory scrutiny, trust companies engage more in actively managed trust businesses generating higher fee income (i.e. loans and other investments). Nevertheless, interest income is stagnating, resulting from a decline in trust beneficiary rights products and subsequent fall in asset under management ${ }^{15}$. At the same time, bank lending has grown to meet loan demand. While this is a policy decision to reduce the economy's reliance on shadow banking, growing banking concentration risk and financial sector linkages raise the potential for the transmission of financial shocks among savers, banks and bond market ${ }^{16}$.

The development of the non-bank credit intermediation sector offers ample opportunities for additional funding sources, risk management and new investment vehicles that are tailored to the needs of actual market participants. However, resulting tight and growing financial sector linkages further raise the potential for the transmission of financial shocks among savers, banks and bond market. Also, the development and adoption of innovative WMPs, while bringing potentially high profitable investment opportunities, may also give rise to the potential risk of unexpected losses without appropriate traditional loss buffers. This might have an extended negative impact on trust sentiment and saving buffers of the wide base of small bank customers. WMPs invest in a wide range of industries, including industries that are vulnerable to weak property market conditions or those experiencing overcapacity. Most WMPs are not explicitly guaranteed by the issuing bank so investors legally assume the risk of these products. A key issue is whether the presumption of implicit guarantees is upheld or the authorities allow failing WMPs to default and investors to experience losses arising from these products. Chinese monetary and regulatory authorities have taken a series of policy actions to address these new sources of risk. The current regulatory approach focuses on reining in rampant regulatory arbitrage activities and has attempted to build a firewall between commercial banks and shadow banks. The People Bank of China $(\mathrm{PBoC})$ has responded to major concerns on leverage by tightening interbank liquidity ${ }^{17}$. 
Figure 3.4. The absolute and relative size of the shadow banking sector in selected economies, 2018
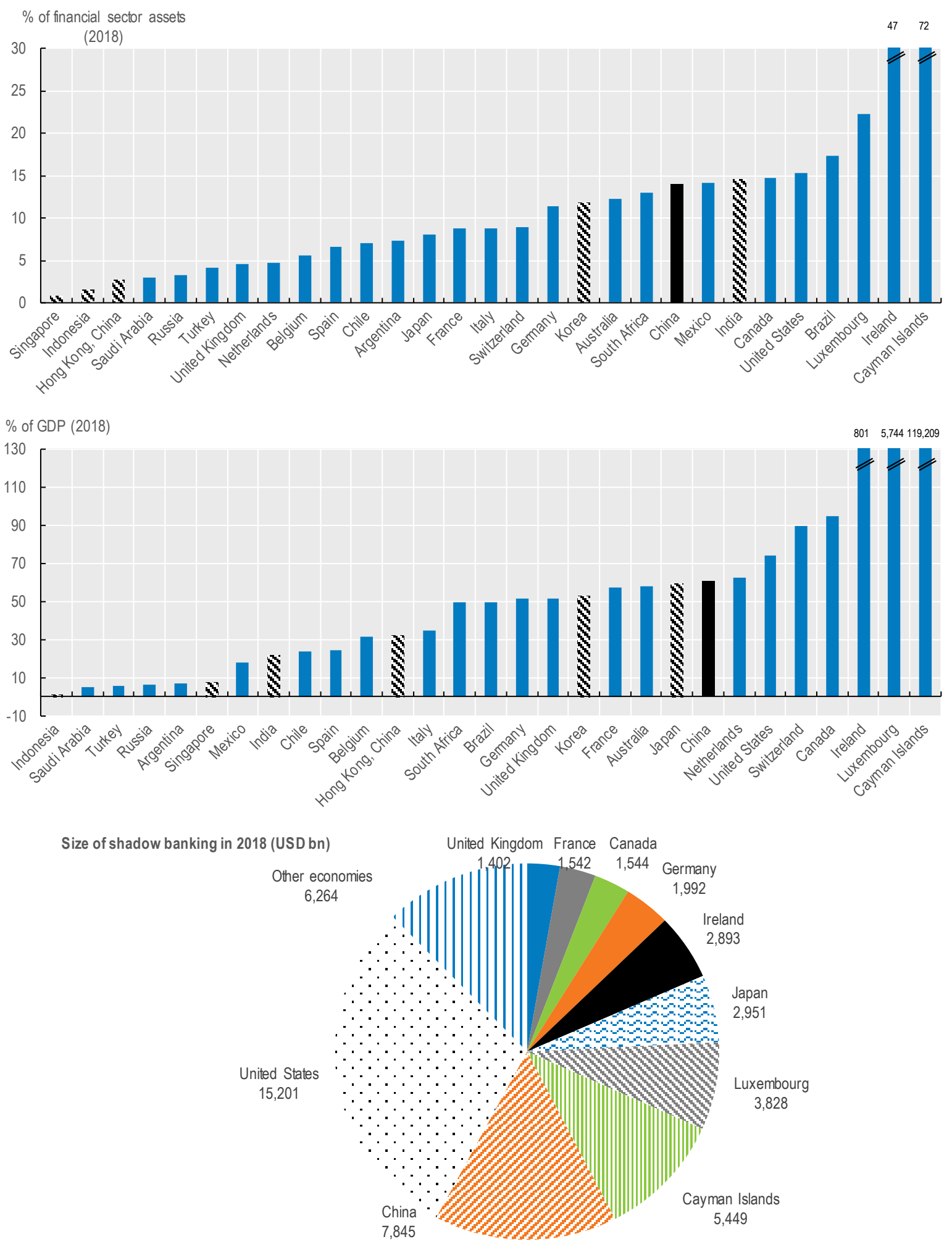

Source: Financial Stability Board 2019 Shadow Banking Monitoring Report, IMF World Economic Outlook database, OECD calculations. 
Figure 3.5. The assets of banks and the shadow banking sector in China, 2006-2019
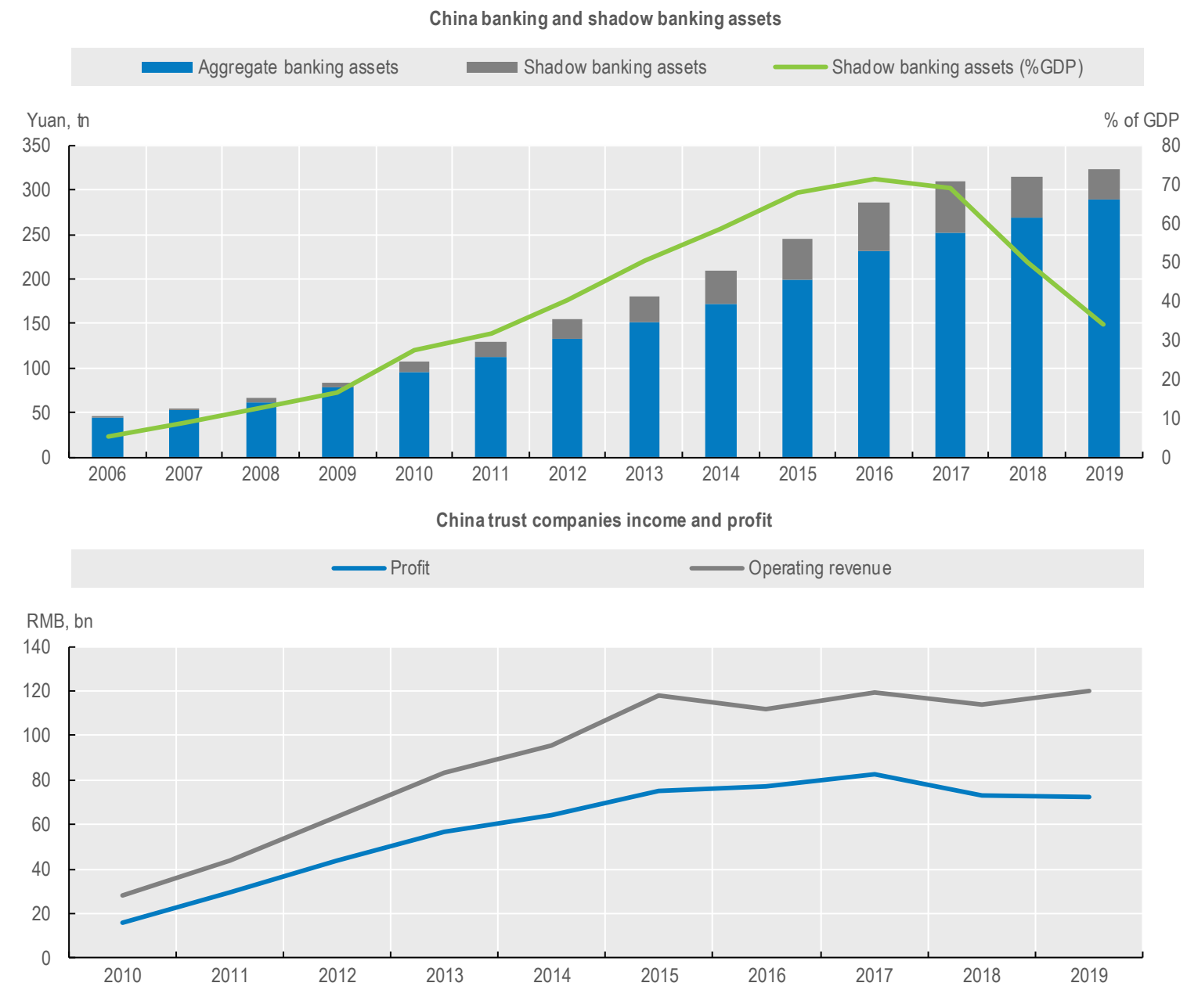

China trust companies revenue breakdown by income source

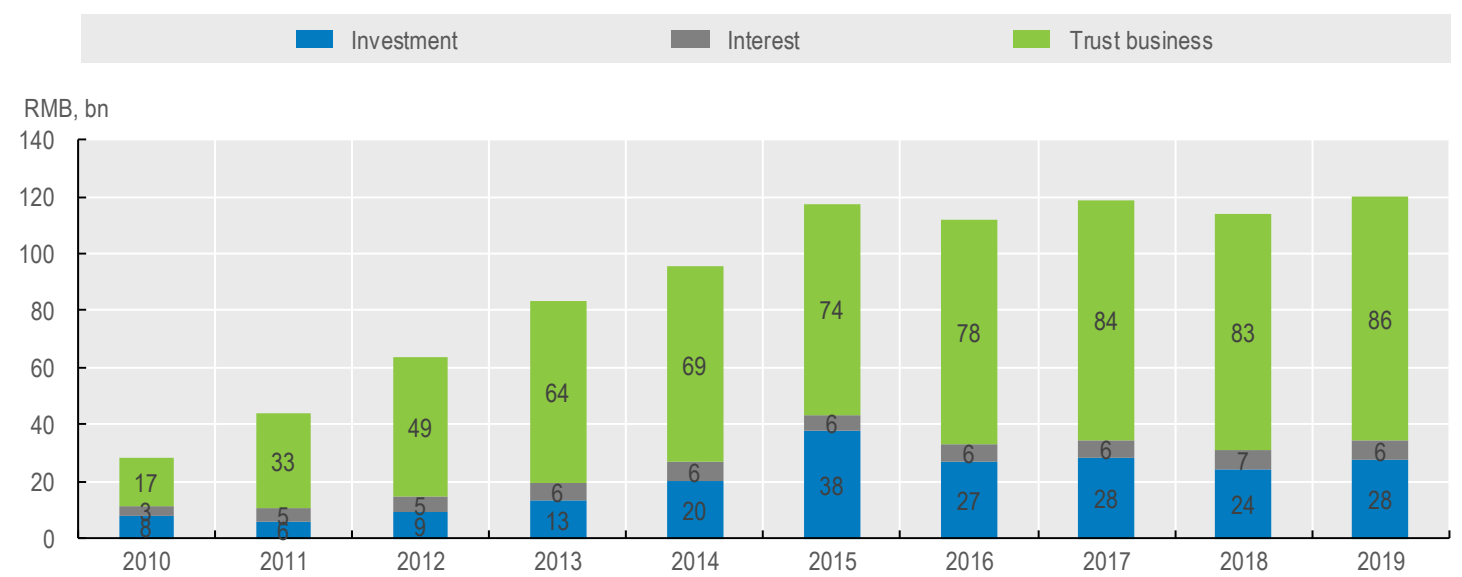

Note: Most shadow financing in China includes undiscounted bankers' acceptances, trust and entrusted loans and wealth management products (WMPs).

Source: China Banking and Insurance Regulatory Commission, China Trustee Association, CEIC, Bloomberg, Refinitiv, OECD calculations. 
Overall, worsening global growth prospects may erode the debt sustainability of these leveraged products, and could contribute to considerable rating downgrades and defaults. These negative market dynamics could contribute to significant losses among Chinese financial institutions, which in turn may erode economic growth. This would have negative spillovers to international trade, commodities and capital markets.

\subsection{The rapid growth of FinTech credit}

Credit intermediation provided by Fintech companies or platforms has grown rapidly around the world in recent years, but its size still varies greatly across economies. Given the importance of financing (either credit or equity) for the economy, this section focuses on the development of FinTech. According to the Cambridge Centre for Alternative Finance (2020), "FinTech comprises various lending, investment and non-investment models that enable individuals, businesses and other entities to raise funds via an online marketplace. Typically, these fundraisers satisfy their funding needs through pooled funds from a 'crowd' or network of retail and/ or professional investors. As the ecosystem has evolved, clear model types have emerged and become more delineated and sophisticated."

Available data show that FinTech volume has expanded rapidly in many countries over recent years, albeit from a very low base. Estimates from the Cambridge Centre for Alternative Finance $(2020)^{18}$ indicate that the global FinTech industry facilitated USD 305 billion in transaction volume in 2018 (Figure 3.6). This total volume represents a $27 \%$ annual decline against the USD 419 billion recorded in 2017. However, this drop in global volume stems primarily from a sharp decline in FinTech activities in China. Nevertheless, China is the world's largest FinTech market which represented $71 \%$ of overall global volume in 2018 . The two largest models in the Chinese FinTech market are peer-to-peer marketplace consumer lending and peerto-peer marketplace business lending, which combined accounted for $95 \%$ of the overall market volume in 2018 (Table 3.1).

Figure 3.6. Total FinTech volume, 2015-2018

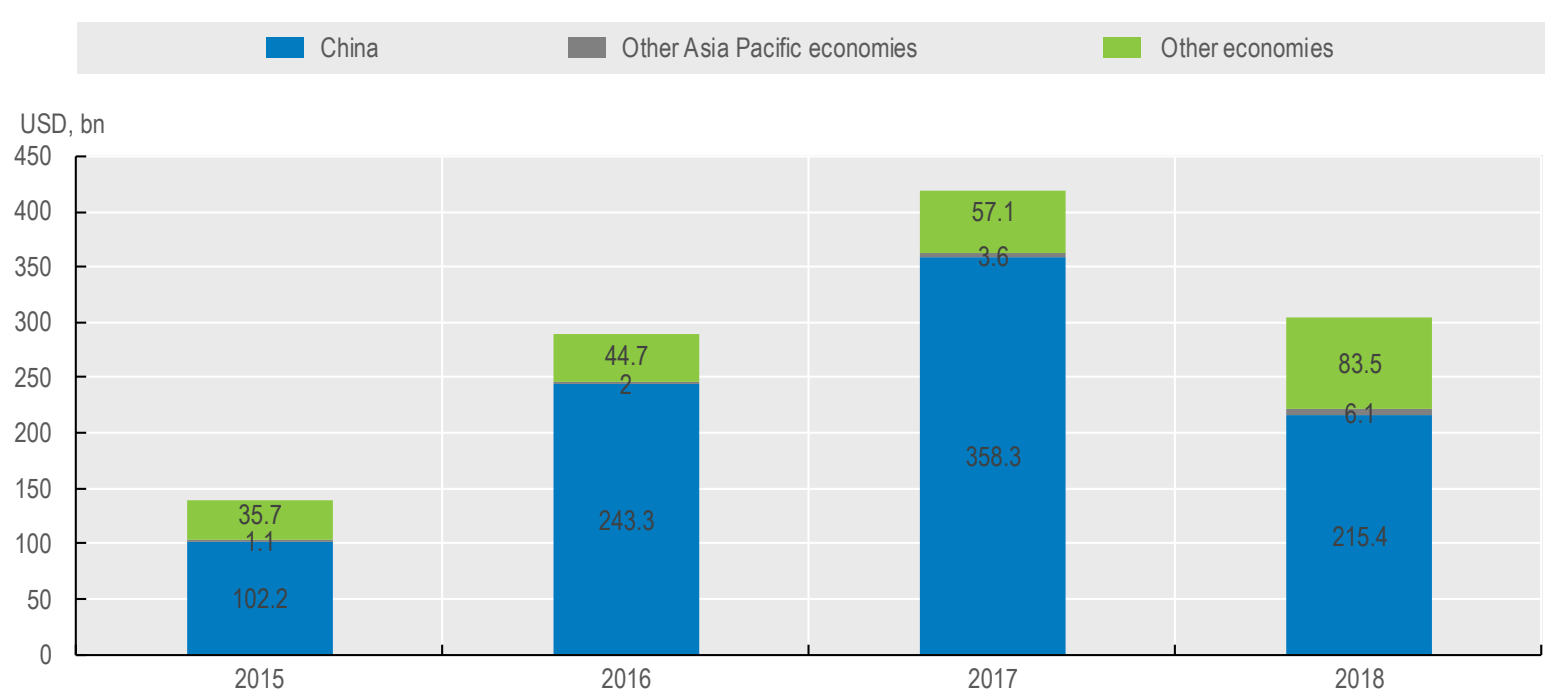

Note: This chart presents global Fintech volume in the form of debt and equity.

Source: Cambridge Centre for Alternative Finance (2020). 
Table 3.1. Total Fintech volume by region and model categories, 2018

\begin{tabular}{|c|c|c|c|}
\hline Region & Debt & Equity & Non-investment \\
\hline China & 215370 & 22 & 6 \\
\hline United States & 57670 & 2550 & 697 \\
\hline United Kingdom & 9310 & 870 & 77 \\
\hline Europe & 6600 & 883 & 238 \\
\hline Asia Pacific & 5340 & 505 & 277 \\
\hline Latin America and the Caribbean & 1700 & 46 & 39 \\
\hline Middle-East & 754 & 36 & 11 \\
\hline Canada & 706 & 44 & 159 \\
\hline Africa & 184 & 12 & 14 \\
\hline
\end{tabular}

Source: Cambridge Centre for Alternative Finance (2020).

The shadow banking sector in China is growing more diverse and complex with the expansion of FinTech credit at a fast pace. Several unique factors have contributed to the more rapid rise of FinTech credit in China, and also more broadly in the Asia region, such as user convenience, accessibility and pricing.

The relative availability of financial services ${ }^{19}$ is a comparative advantage of Fintech firms compared to traditional credit intermediaries such as banks. The ability of FinTech platforms to provide online services and user-friendly experience may give them some competitive advantage over traditional intermediaries which are dealing with legacy infrastructure and processes. Risk information is provided, and loan application processes conducted online, reducing search costs and speeding up the process for borrowers. A study by Ernst and Young (2017) suggests that Chinese consumers, merchants and investors have enthusiastically embraced mobile technology for financial transactions, including payments.

FinTech lending may be seen as an alternative funding source for existing borrowers who were previously shut out of the formal bank credit market, notably SMEs (FSB, 2017c). Cornelli et al. (2019) suggest that Fintech firms have helped SMEs previously disadvantaged by limited credit history and has the potential to address a key problem in many Asian countries that lack comprehensive credit bureau coverage. FinTech firms have a comparative advantage over incumbent banks for credit scoring approach by using machine learning that provide a direct and rapid assessment of credit risk. In particular, it can improve underwriting, draw on information from relationships between customers, and, in some cases, prevent human bias from entering the decision.

In terms of pricing, Fintech credit rates, though higher than those of banks, are far lower than the private lending rates available for such borrowers (Figure 3.7). In principle, FinTech lending platforms have the potential to offer lower interest rates to borrowers because the intensive use of digital technologies reduces operating costs by removing the need for physical branch networks and allowing automation of loan application, credit risk assessment and pricing processes ${ }^{20}$. In addition, FinTech lenders are facing lower regulatory costs compared to banks that are subject to stringent regulatory framework. For example, in China an initially more permissive regulatory environment encouraged firms to innovate and expand, with a growing number of peer-to-peer platforms supported by the state and venture capital. In recent years, however, the regulatory regime has tightened to improve risk assessment and management ${ }^{21}$. Nevertheless, the benefits for FinTech creditors are challenging to quantify because of the difficulty to identify alternative investments with similar risk characteristics. In fact, FinTech loan investments are a new asset class for retail investors, distinct from lower-yielding bank deposits and more diversified than single-company company debt exposures. 
Figure 3.7. Selected Chinese lending interest rates, 2013-2018

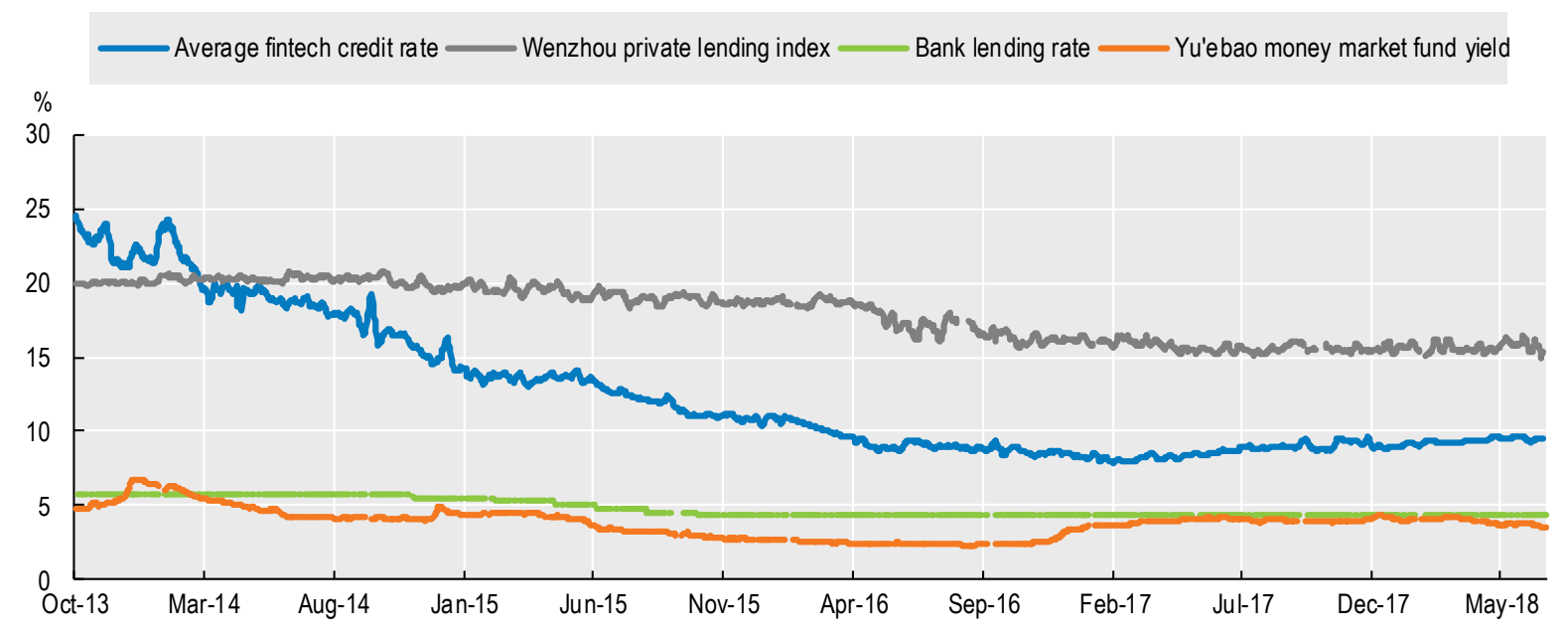

Note: Average FinTech credit rate is calculated as the seven-day moving average of one-year rate. Wenzhou private lending index is released by the Wenzhou Municipal Government Finance Office and tracks private lending. Yu'ebao money market fund yield refers to the seven-day rate. Bank lending rate is prime lending rate.

Source: CEIC, WDZJ.com, Wind, The Peoples Bank of China, BIS Quarterly Review September 2018.

China's Fintech industry is facing challenges to its sustainability against the background of economic downturn, tightened liquidity and stricter financial regulations. Notably, the modalities and risks in the Chinese FinTech credit market have changed over time. In the early period following its inception in 2007, FinTech credit firms in China operated simple matching models, whereby investors bid for contracts offered by borrowers. From around 2012 onwards, platforms moved to more complex structures where investor funds were pooled ${ }^{22}$. Many platforms are directly subject to credit risk as they provide guarantees on loan principal and interest ${ }^{23}$ and promised "rigid redemptions". Risks have risen due to inappropriate market practices and fraud, including Ponzi schemes. Notably, in an environment where regulation and supervisory oversight was either missing or inadequate, business models such as payday and largely unregulated 'campus loans' for students developed rapidly in China ${ }^{24}$. Borrowers have been incentivized to increase their indebtedness without the realistic prospect of repaying their loan. Defaults have surged and the cumulative number of problem platforms in China have continuously increased from 93 in 2013 to 2667 in 2018 (Figure 3.8). Since 2016, Chinese authorities have implemented regulatory measures ${ }^{25}$ including the establishment of a clear upper limit for borrowing costs and improvements to financial education $^{26}$. In 2017, the formation of China's marketplace lending supervision ' $1+3$ ' system (i.e, 'one method, three guidelines') has been implemented. The objective is to improve monitoring, management, and control of industry risks. Local regulatory authorities have established regulations which are in accord with national industry developments, whilst factoring in regional variations. In the context of rising defaulted platforms over the recent years, authorities have accelerated the process of improving the regulatory system and launched numerous initiatives to ensure that firms implement effective winddown plans, to mitigate risk associated with liquidation and platform transformation. Industry self-regulation plays also a crucial role in reducing the regulatory burden and cost, eliminating the information asymmetry between the market subject and the regulatory body and in improving professionalism and market standardization. Lastly, Chinese marketplace lending platforms are collaborating with banks and have established fund depositary relationships. 
Figure 3.8. Cumulative failed FinTech lending platforms in China, 2013-2019

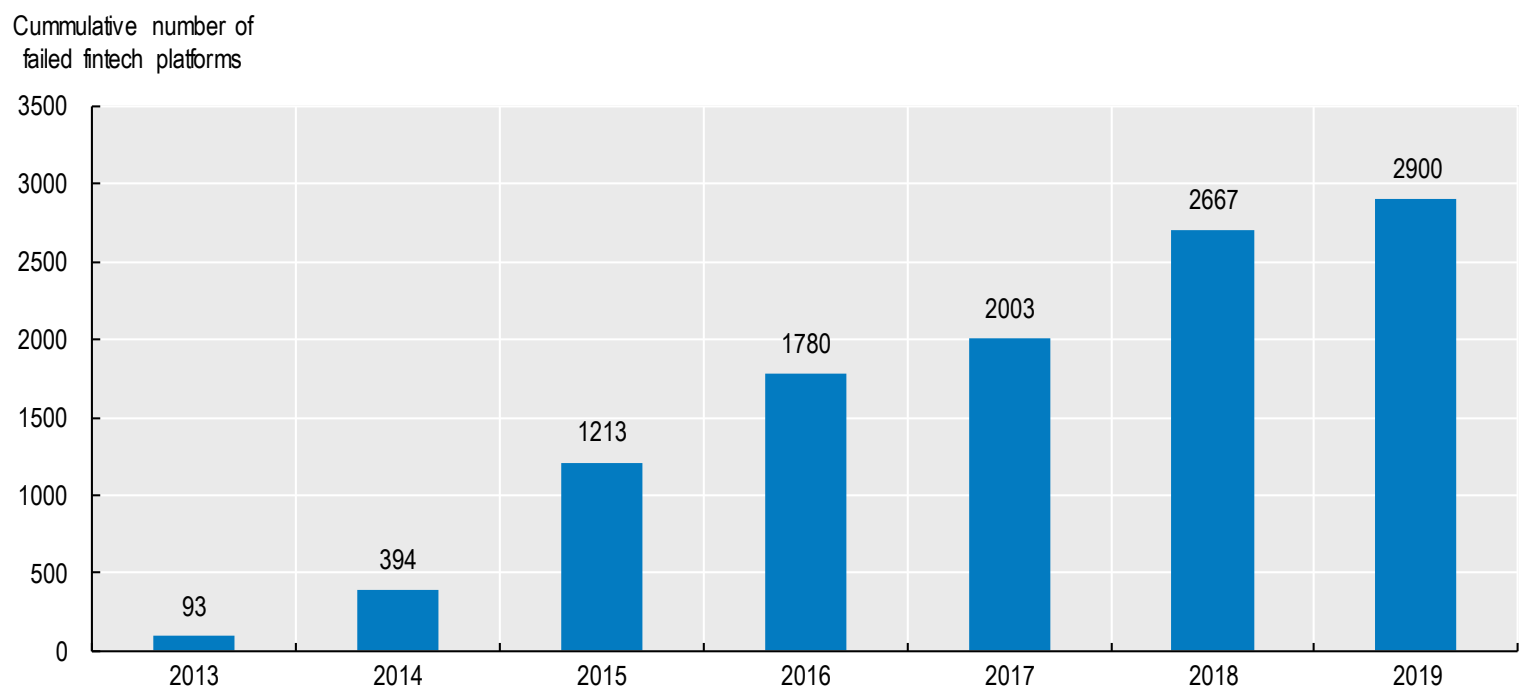

Source: WDZJ.com, OECD calculations.

While stronger regulation helped China's FinTech credit industry to gradually stabilize, analyses of FinTech lending markets highlight current challenges including rapid market developments and the fragmented nature of the markets; lack of transparency; and data gaps that hamper proper assessment of risks. Innovations in FinTech lending, while bringing cost efficiencies and improving access for some underserved segments of the population, may also give rise to potential risks of unexpected losses on lending platforms, which do not have the traditional loss buffers. Large MMFs may also pose systemic risks, as they could be subject to investor runs in the event of credit or duration losses. Public authorities are considering these risks. The PBoC and the China Securities Regulatory Commission (CSRC) have introduced a cap on instant redemptions on MMFs. At the same time, they have increased disclosure obligations for lenders that should take into account the repaying ability of borrowers as a condition to extend loans ${ }^{27}$. Overall, these emerging risks may question the perennial existence and the reputation of the FinTech lending industry. They may also warrant the consideration of policy makers to both secure and improve business practices in the sector to better protect investors and borrowers. These questions will become crucial in the context of the Covid-19 crisis that is affecting the economy. A large number of private enterprises will need financial services and access to finance. If well regulated, the FinTech industry could play a key role to provide more effective, accessible and affordable financial products and services. Regulatory authorities should pay close attention to the near future developments in the FinTech industry to help FinTech financial intermediation develop in a manner to promote more inclusive and sustainable finance in China. 


\section{Equity markets}

Another prominent development in Asian financial markets is the rapid growth of Asian equity markets both in absolute and relative terms. Asian companies have become the world's largest users of public equity financing ${ }^{28}$. Already in 2006 Asian non-financial companies raised more public equity than firms from the United States. And in 2018 they accounted for $44 \%$ of the global volume of equity raised. They have now surpassed the combined share of Europe and the United States (Figure 4.1). Trade tensions, concerns about economic growth and other geopolitical issues (such as Brexit and social unrest in Hong Kong) affected IPO activity for much of 2019. Nevertheless, Asia-Pacific IPO activity has remained relatively resilient. According to Ernst and Young (2019), Asia-Pacific accounted for seven of the top ten exchanges by deal numbers and five of the top ten by proceeds in 2019. Given the Covid-19 outbreak and its negative impact on global economic activities, IPO markets are expected to be negatively impacted in $2020^{29}$. Unexpected and novel events surrounding Covid-19 took a toll on the global health of equity markets and, together with other global market factors, have caused market turbulence last seen only during the global financial crisis of 2008 . Therefore, resulting extreme market volatility makes any ambitions for corporates to go public highly uncertain, both in terms of timing and valuation.

\section{Figure 4.1. Share of Asian non-financial companies in global public equity financing, 2000-2018}

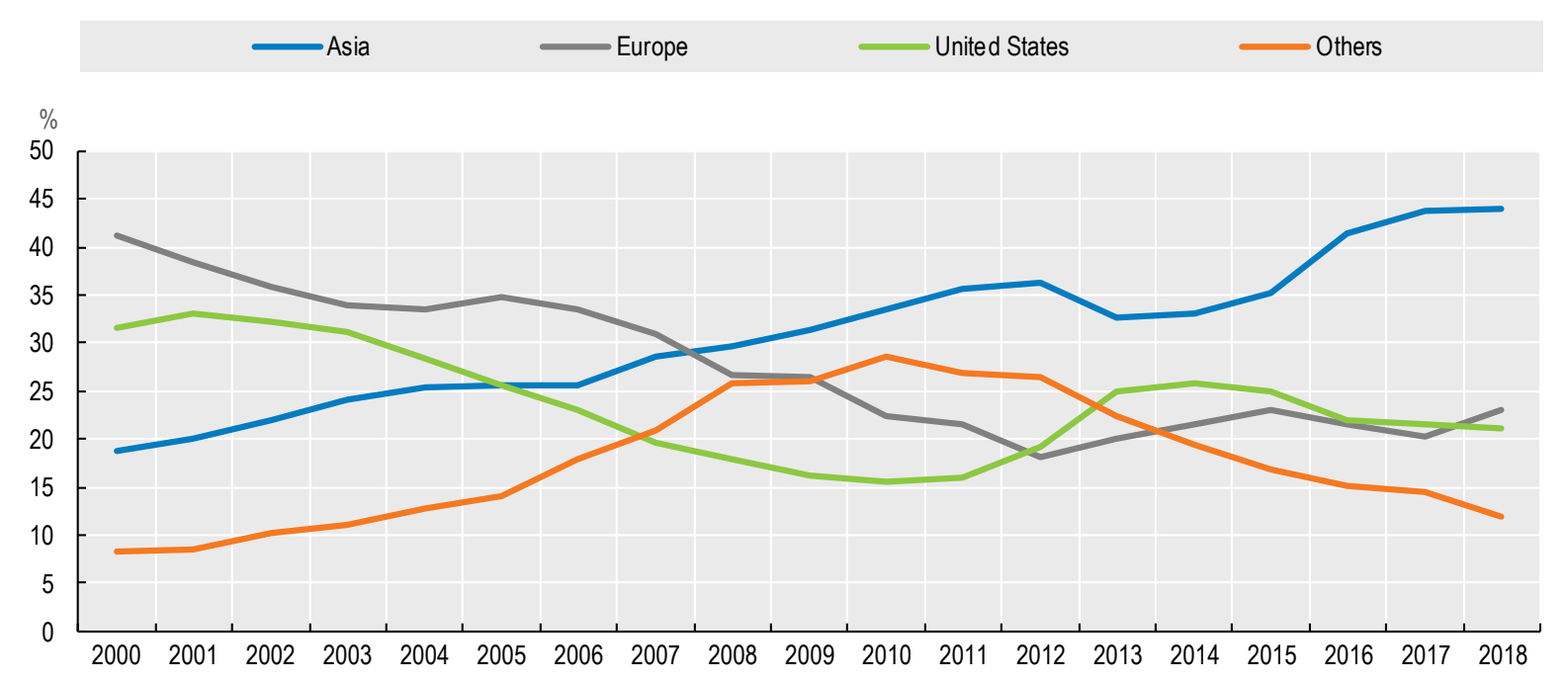

Note: Equity financing is the sum of annual Initial Public Offerings (IPOs) and Secondary Public Offerings (SPOs) proceeds. Regional shares are calculated as a three-year moving average.

Source: OECD Capital Market Series dataset, OECD Equity Market Review Asia 2019.

Financial and technological innovation is also important to consider in the case of Asian economies, given its role on fostering economic growth and recent developments in equity markets. In global context, Asia has experienced a steady increase in the amount raised through technology IPOs and has become the world's largest market over the period 2014-2017 (Figure 4.2). 
Figure 4.2. Technology IPO proceeds, as a percentage of total IPO proceeds, 2006-2017

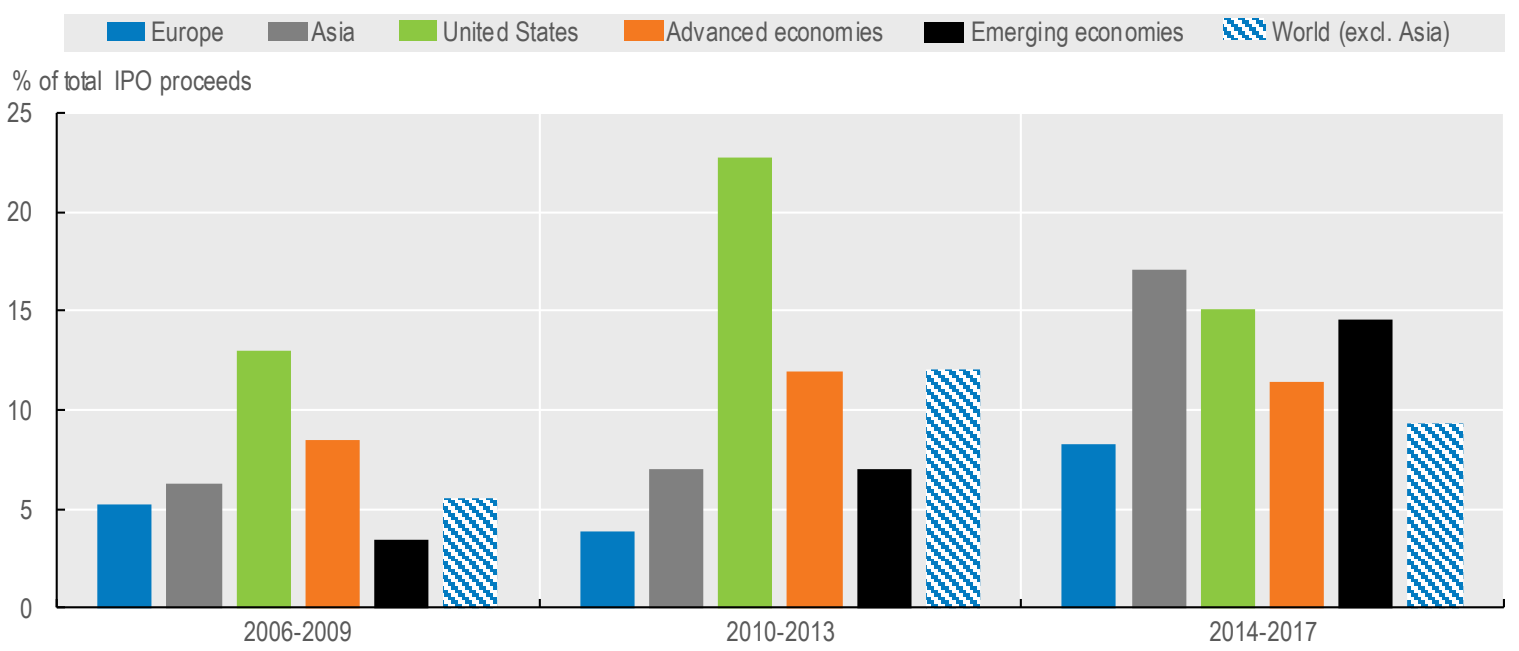

Note: Percentage share represents a 4-year average. The information technology sector contains the six following industries: software and IT services, communication and networking, semiconductors and semiconductors equipment, office equipment, electronic equipment, computers, phones and household electronics.

Source: OECD Capital Market Series dataset, OECD Equity Market Review Asia 2018.

Since 2014, Initial Coin Offerings (ICOs) have also emerged as an additional innovative financing instrument ${ }^{30}$. Globally, ICOs have raised nearly USD 19 billion in the period from 2014 to August 2018 from insignificant amounts recorded in in 2014 and 2015 (Figure 4.3).

Figure 4.3. Initial Coin Offering (ICO) proceeds as a share of global IPO proceeds, 2014-2018

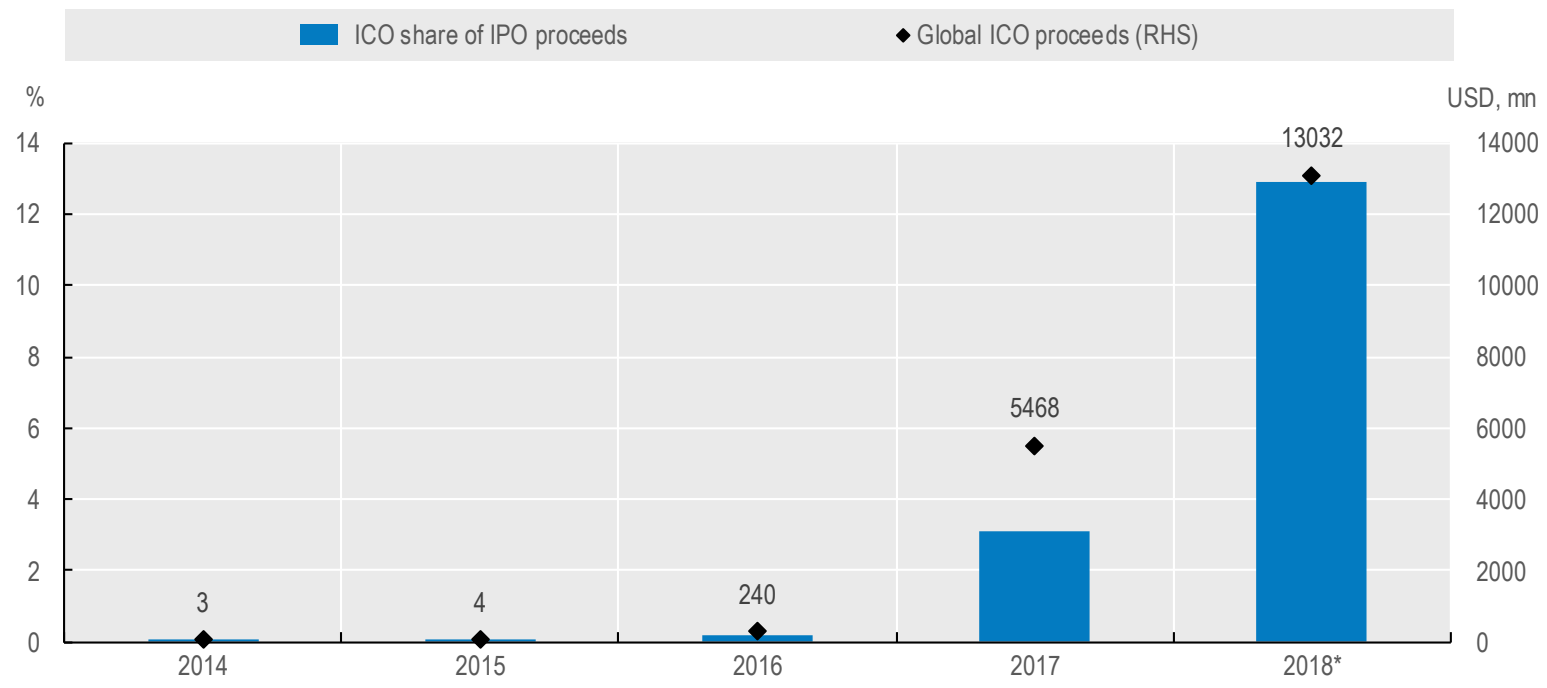

Note: *2018 IPO value is displayed as a share of 2017 January to August IPO proceeds. The graph above represents the USD million amount of 868 completed ICOs. The TokenData dataset includes information on 2277 ICOs performed between 2014 and August 2018, however only 868 ICOs have a recorded deal value.

Source: TokenData dataset, OECD Equity Market Review Asia 2018.

Even if companies based in the Cayman Islands, United States, and the British Virgin Islands raised the largest amount of capital through ICOs, Asia is a regional destination for ICOs with USD 2.4 billion raised 
(Figure 4.4). A cross section of Asian economies feature in the list: Singapore, China (including Hong Kong, China), Korea, Japan, and India that have jointly raised over $95 \%$ of this total amount. Some of the concerns raised over ICOs include the lack of clarity over the treatment of tokens as traded assets, lack of regulation in some markets, including disclosure requirements, and very limited investor protection. Therefore, attention to strengthening investor and financial consumer protection, disclosure and valuation will be important to build public trust.

\section{Figure 4.4. Distribution of global issuance of ICOs by domiciliation, 2014-2018}

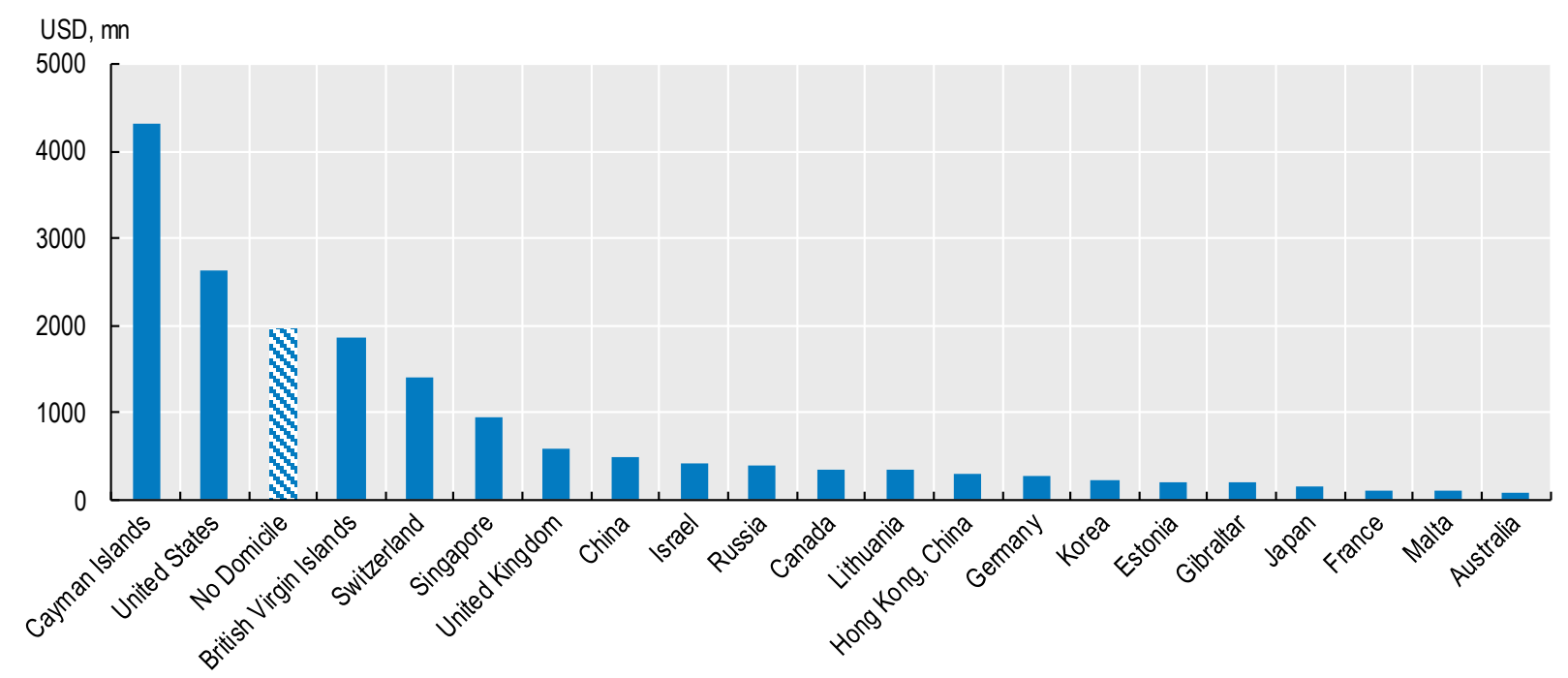

Source: TokenData dataset, OECD Equity Market Review Asia 2018.

Stronger capital markets in Asia and in particular the development of equity financing could overcome some funding constraints stemming from strong reliance on bank financing. It may also help address the issue of high indebtedness in the Asian corporate sector and provide for a better risk transfer and risk sharing among market participants. A favourable development in equity markets seems therefore key in providing the necessary support to sustainable economic growth in the region.

Nevertheless, actual developments of equity financing should be analysed in light of the concerns over substantial build-up of debt of non-financial corporations as discussed in section 2.2. In fact, non-financial corporate debt issuers are highly leveraged to cash flows in most Asian economies compared to other regions over the period 2004-2019. However, non-financial corporate debt Asian issuers are facing rising debt to equity ratios, mainly in China and India (Figure 4.5). Therefore, debt issuance of Chinese and Indian non-financial corporates has outpaced their equity issuance. Also, the ratio of EBITDA to equity is falling for non-financial corporates in most emerging Asian economies, including China and India (Figure 4.6). This suggests that non-financial corporates are experiencing lower cashflows to repay debt in emerging Asia, and their earnings are falling at a higher pace compared to the growing pace of their equity.

This analysis illustrates that financial intermediation has been more oriented to debt financing rather than to equity in the post-crisis era, mostly in emerging Asian economies. The combination of rising levels of indebtedness, leverage and deteriorating earnings may erode the debt sustainability of some leveraged issuers with limited equity buffers. 
Figure 4.5. Non-financial listed companies' debt to equity ratio for selected Asian economies, 20042019

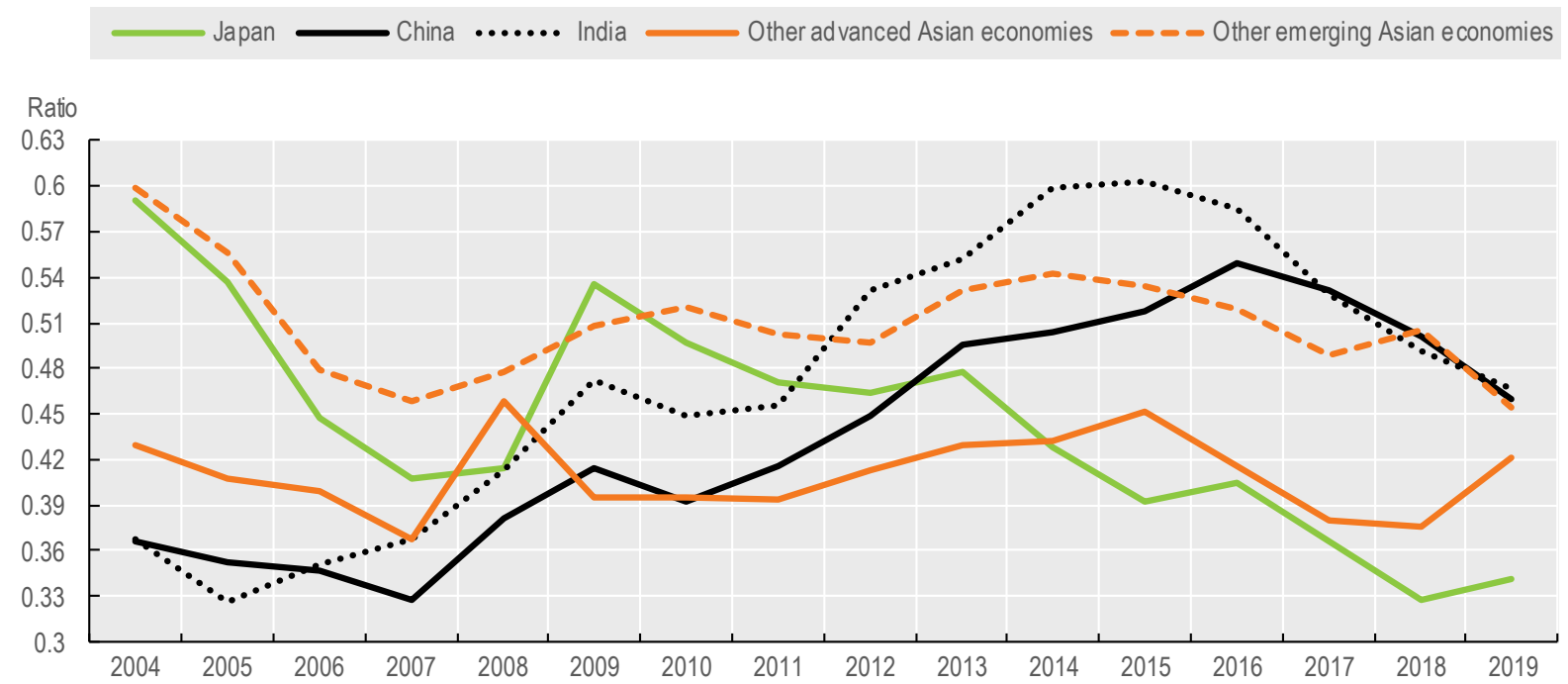

Note: Total debt includes loans and short and long term bonds. Total equity represents the total investment in the company. It is the sum of common equity, preferred stock, minority interest, long-term debt, non-equity reserves and deferred tax liability in untaxed reserves. Debt to equity ratio calculations are performed using a global sample of 12,220 listed non-financial companies with available financial statement data in Refinitiv over the period 2004-2019. Annual consolidated financial statements are collected on an annual basis, at the firm level and in current USD. All data are trimmed at the 1st and 99th percentile levels to reduce the effect of outliers.

Source: Refinitiv, OECD calculations.

Figure 4.6. Non-financial listed companies' EBITDA to equity ratio for selected Asian economies, 2004-2019

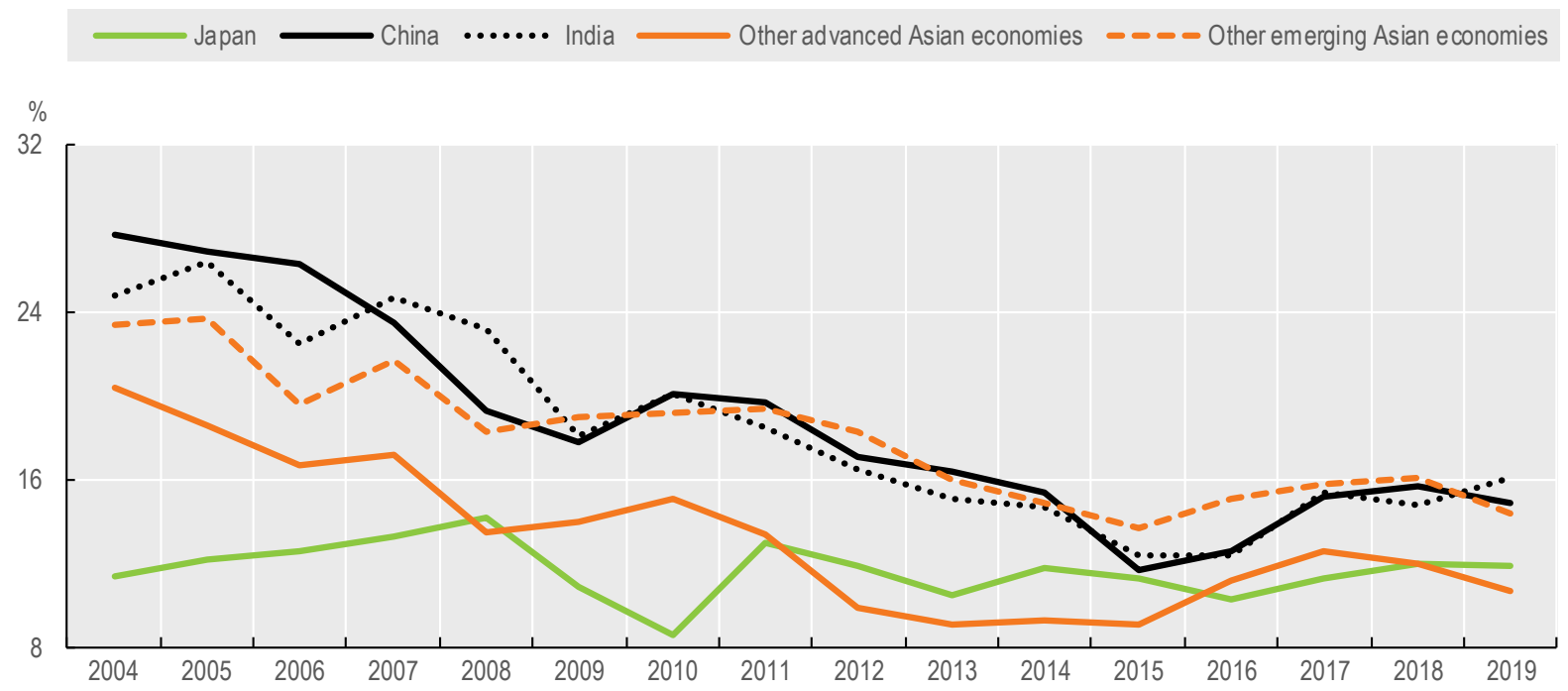

Note: EBITDA represents income before interest, taxes, depreciation and amortisation. Total equity represents the total investment in the company. It is the sum of common equity, preferred stock, minority interest, long-term debt, non-equity reserves and deferred tax liability in untaxed reserves. EBITDA to equity ratio calculations are performed using a global sample of 12,220 listed non-financial companies with available financial statement data in Refinitiv over the period 2004-2019. Annual consolidated financial statements are collected on an annual basis, at the firm level and in current USD. All data are trimmed at the 1st and 99th percentile levels to reduce the effect of outliers. Data are expressed in percentage.

Source: Refinitiv, OECD calculations. 


\section{Summary and conclusions}

As documented in this paper, Asia experienced strong overall capital market development over the last two decades, supported by a changing structure in the form of financial intermediation. While experiences have differed by country, the growth of capital markets and profound changes in the structure of the financial system have been coupled with an increase in levels of debt and leverage, maturity and liquidity transformation. Such underlying risks, in a context of tightening global economic conditions and regulatory arbitrage in some parts of the system, require scrutiny to ensure the financial system is more resilient and is able to underpin more inclusive and sustainable economic growth. Four major developments have been discussed in this paper and their policy implications deserve particular consideration.

The moderate, yet growing level of sovereign debt and rapid growth of emerging Asian non-financial corporate debt has provided the necessary support to deliver strong economic growth. While not necessarily a financial stability risk for many countries, it could be argued that the combination of rising public debt and deteriorating fiscal positions may hinder the use of additional fiscal stimulus during a protracted downturn, and could subject issuers to much higher refinancing costs in a less benign macro environment. Principles on debt management strategy and risk frameworks should be given careful consideration to ensure the appropriate balance between minimizing funding costs and addressing refinancing risks, including under periods of acute market stress ${ }^{31}$.

In the case of corporate debt, the rising leverage to cash flow of many issuers is a major concern as worsening global growth perspectives, notably following the Covid-19 outbreak, will erode debt sustainability and could contribute to a sharp rise in defaults as the credit cycle turns. A collective action problem arises because there is no clear public oversight over the levels of corporate debt and their implications, notwithstanding systemic surveillance of financial stability risks. Market-based forces for restraining excessive corporate debt have been effective in the era of modern finance. However, signs of excessive exuberance during periods of highly accommodative monetary policy have already imposed some limitations. A more proactive approach should consist of improving the assignment and communication of the level of risk concerns by central authorities, so that markets can better interpret the potential for systemic risks to weigh on corporate credit markets. It is worth noting that the expansion of Asian equity markets and the equity financing are also effective cushions to partially mitigate some of these indebtedness challenges. High equity financing enables better risk transfer and sharing among market participants and is therefore a key strength to support sustainable economic growth in the region. Despite, equity markets have expanded substantially, financial intermediation has been more oriented to debt financing rather than to equity in the post-crisis era, mostly in emerging Asian economies. Therefore, the combination of rising levels of indebtedness, leverage and deteriorating earnings is rising concerns about the debt sustainability of some leveraged issuers with limited equity buffers.

The growing importance of market-based finance, particularly in China, while offering ample opportunities for additional funding sources and risk management may also give rise to potential risk of unexpected losses. Resulting tight and growing financial sector linkages further raise concerns regarding systemic risk. The current regulatory approach focuses on reining in rampant regulatory arbitrage activities and has attempted to build a firewall between commercial banks and shadow banks. Further attention to strengthening investor and financial consumer protection and market integrity should be given for financial 
regulators to set-up the monitoring of non-banks, require non-banks to improve risk management and transparency and holdings of appropriate loss buffers.

The recent and rapid growth of FinTech credit undoubtedly has benefits in terms of additional sources of funding, higher diversity and competitiveness within the financial system. However, the fragmented nature of the markets, the lack of transparency and data gaps hamper proper assessment of risks. Emerging risks may warrant the consideration of policy makers to both secure and improve business practices in the sector to better protect investors and borrowers. 


\section{References}

Amstad, M. and He, Z., 2018. Chapter 6: Interbank System, Handbook of China's Financial System, edited by Marlene Amstad, Guofeng Sun and Xiong Wei.

Asian Development Bank, 2017. Meeting Asia Infrastructure Needs, Asian Development Bank, www.adb.org/sites/default/files/publication/227496/special-report-infrastructure.pdf.

Asian Development Bank, 2019. ASEAN+3 Bond Market Guide: Exchange Bond Market in The People Republic of China, https://asianbondsonline.adb.org/documents/abmf prc bond market guide 2019.pdf.

Bank of England, 2017. Market-based finance: a macro prudential view, Speech given by Sir Jon Cunliffe, Deputy Governor Financial Stability, Member of the Monetary Policy Committee, Member of the Financial Policy Committee and Member of the Prudential Regulation Committee.

Bank for International Settlements, 2016. Foreign exchange turnover in April 2016, Triennial Central Bank Survey of Foreign Exchange and Derivatives Market Activity, September. BIS, Basel.

Bank for International Settlements, 2019. Big Tech in Finance: Opportunities and Risks. Annual economic report, June.

Beltran, D., Garud,K. and Rosenblum, A., 2017. Emerging Market Non-financial Corporate Debt: How Concerned Should We Be?, IFDP Notes. Washington: Board of Governors of the Federal Reserve System, June 2017. https://doi.org/10.17016/2573-2129.32

Bloomberg, 2019. "For China, Kicking a \$9 Trillion Habit Is Tough Work", June.

Cambridge Centre for Alternative Finance, 2018. The Third Asia Pacific Region Alternative Finance Industry Report, November.

Cambridge Centre for Alternative Finance, 2020. The Global Alternative Finance Market Benchmarking Report, April.

Cheung, Y.-W., McCauley, R., and C., Shu, 2019. Geographic spread of currency trading: The Renminbi and other emerging market currencies. China \& World Economy, 27, 25-36.

Lee, D. K. C. and Deng, R. H., 2017. Handbook of Blockchain, Digital Finance, and Inclusion, Academic Press, Volume 1.

Claessens, S., Frost, J., Turner, G. and F. Zhu, 2018. Fintech credit markets around the world: size, drivers and policy issues. Bank for International Settlements Quarterly Review, September 2018.

Cornelli, G., Davidson, V., Frost, J., Gambacorta, L. and K. Oishi, 2019. SME Finance in Asia: Recent Innovations in Fintech Credit, Trade Finance, and Beyond. ADBI Working Paper 1027. Tokyo: Asian Development Bank Institute.

Ehlers T., Kong, S. and Zhu, F., 2018. Mapping shadow banking in China: structure and dynamics, Bank of International Settlements Working Papers, No 701.

Elliott, J. and K. Yan, 2013. The Chinese financial system: an introduction and overview, John L. Thornton China Center at Brookings.

Ernst and Young, 2017. EY FinTech Adoption Index 2017: the rapid emergence of FinTech.

Ernst and Young, 2019. Global IPO trends: Q4 2019, December.

Ernst and Young, 2020. COVID-19 pandemic cuts global IPO momentum short in Q1 2020, March. 
Financial Stability Board, 2011. Shadow Banking: Strengthening Oversight and Regulation.

Financial Stability Board, 2013. Policy Framework for Strengthening Oversight and Regulation of Shadow Banking Entities.

Financial Stability Board, 2017a. Assessment of Shadow Banking, Reports to the G20.

Financial Stability Board, 2017b. Financial stability implications from FinTech: regulatory and supervisory issues that merit authorities' attention.

Financial Stability Board, 2017c. FinTech credit: Market structure, business models and financial stability implications, Report prepared by a Working Group established by the

Committee on the Global Financial System (CGFS) and the Financial Stability Board (FSB).

Financial Stability Board, 2019. Global Monitoring Report on Non-Bank Financial Intermediation 2019.

Financial Times, 2017. HK renminbi deposits fall at record pace in December, January.

Fitch Ratings, 2020. Defaults Among Chinese State-Owned Enterprises, March.

Garcia Herrero, A, 2019. Hong Kong's economy is still important to the Mainland, at least financially, Bruegel blog post, August.

Hack, M., and Close, C., 2013. East Asian Corporate Bond Market. Reserve Bank of Australia, Quarterly Bulletin, September.

Hong Kong Monetary Authority, 2016. The Global Offshore Renminbi Business Hub, January.

Hong Kong Monetary Authority, 2019. Half-Yearly Monetary \& Financial Stability Report, September.

Hong Kong Monetary Authority, 2020. Half-Yearly Monetary \& Financial Stability Report, March.

International Monetary Fund, 2016. China spillovers: New evidence from time varying estimates, Spillover Task Force Note, November.

International Monetary Fund, 2017. Fintech and financial services: initial considerations, IMF Staff Discussion Notes, no 17-5.

International Monetary Fund, 2020. People's Republic of China, Hong Kong special administrative region, 2018 article IV consultation IMF reports 19/20.

KPMG, 2017. Review and Outlook of Chinese Banks in Hong Kong, December.

Lin, F., Lei, L. and L. Zhou, 2019. A brief introduction to China's bond market, ACCRA and Golden Credit Rating joint research.

Liu, K., 2020. Hong Kong: Inevitably irrelevant to China?, Economic Affairs, Wiley Blackwell, vol. 40(1), pp. 2-23, February.

McKinsey, 2013. Between deluge and drought: Liquidity and funding for Asian banks, McKinsey Working Papers on Risk No 45.

Moody's, 2020. High-yield non-financial companies - Asia-Pacific 2020: APAC high-yield default rate to rise as coronavirus disruptions raise default risk, April.

OECD, 2018a. OECD Business and Finance Outlook 2017, OECD Publishing, Paris, https://doi.org/10.1787/9789264274891-en.

OECD, 2018b. Financial Markets, Insurance and Private Pensions: Digitalisation and Finance, OECD Publishing, Paris, http://www.oecd.org/finance/private-pensions/Financial-markets-insurancepensions-digitalisation-and-finance.pdf

OECD, 2018c. Equity Market Review Asia 2017, OECD Publishing, Paris, http://www.oecd.org/daf/ca/OECD-Equity-Market-Review-Asia-2017.pdf.

OECD, 2019a. Economic Outlook for Southeast Asia, China and India 2020: Rethinking Education for the Digital Era, OECD Publishing, Paris, https://doi.org/10.1787/1ba6cde0-en.

OECD, 2019b. Equity Market Review Asia 2018, OECD Publishing, Paris, http://www.oecd.org/daf/ca/OECD-Equity-Market-Review-Asia-2018.pdf. 
OECD, 2019c. Initial Coin Offerings (ICOs) for SME Financing, available at http://www.oecd.org/finance/lCOs-for-SME-Financing.pdf.

OECD, 2019d. OECD Economic Surveys: China, April, available at http://www.oecd.org/economy/surveys/china-2019-OECD-economic-survey-overview.pdf.

OECD, 2020. The Impact of COVID-19 on the Financial Resilience of Global Financial Markets Surveillance, OECD Committee on Financial Markets, https://www.slideshare.net/OECD-DAF/theimpact-of-covid19-on-the-financial-resilience-of-global-financial-markets.

Pei, J., Yang, C., and S., Yao, 2015. Trade impact of China's transition to the 'new normal'. In B. Hoekman (Ed.), The Global Trade Slowdown: A New Normal? (pp. 253-266). London: Centre for Economic Policy Research.

PBC-CSRC, 2018. Guiding opinions on further regulating the services relating to the internet sales and redemption of money market funds, http://www.csrc.gov.cn/pub/zjhpublic/zjh/201806/t20180601 339014.htm.

Reinhart, C., M., and Rogoff, K., S., 2011. The Forgotten History of Domestic Debt, Economic Journal, Royal Economic Society, vol. 121(552), pages 319-350, 05.

Reinhart, C., M., and Rogoff, K., S., 2014. This Time is Different: A Panoramic View of Eight Centuries of Financial Crises, Annals of Economics and Finance, Society for AEF, vol. 15(2), pages 1065-1188.

Reuters, 2020. How important is Hong Kong to China as a free finance hub?, May.

Shaghil, A., Correa, R., Dias, D., A., Gornemann, N;, Hoek, J., Jain, A., Liu, E., Wong, A., 2019. Global Spillovers of a China Hard Landing, Board of Governors of the Federal Reserve System, International Finance Discussion Papers 1260.

Shen, Y., and Li, C., 2018. “网络借贷风险缓释机制研究” (research on the risk relief mechanism of internet financing), Institute of Digital Finance, Beijing University.

S\&P Global Ratings, Default, transition, and recovery: 2018 annual global corporate default study and rating transitions.

The Economist, 2020. Can Hong Kong remain a global financial centre?, June.

Wei, S.-J., Xie, Z., and X., Zhang, 2017. From Made in China to Innovated in China: Necessity, prospect, and challenges, Journal of Economic Perspectives, 31(1), 49-70.

Zenglein, J. and Kärnfelt, M., 2020. Financial hub at risk: How China's reaction to protests jeopardizes Hong Kong's status, Mercator Institute for China Studies.

Zhang, X., and H., Yuk, 1998. Determinants of Hong Kong manufacturing investment in China: A survey. Marketing Intelligence and Planning, 16(4), pp. 260-267. 


\section{Annex A. Economic and Financial linkages between Hong Kong, China, and Mainland China}

Economic and financial linkages between Hong Kong, China, and China have deepened over the last two decades. The contributing share of Hong Kong, China, in Mainland China's overall GDP has reduced since the mid-1990s (Figure A.A.1), yet financial sector data highlights the important role that the financial sector in Hong Kong, China, plays in China's growth. The competitiveness of the financial sector in Hong Kong, China, has been strengthened due to the free movement of capital and information; a simple tax system; sound regulatory system; strong rule of law, and; high quality professional services. Benefiting from the city's open capital account, Hong Kong, China, has become a leading financial centre for Chinese firms through banking, bond, and stock markets, and is also a gateway for foreign direct investment in and out of Mainland China. China's rapid economic growth has also provided vast opportunities for international investors to expand their business in Mainland China. Therefore, Hong Kong, China has been a major financial hub to channel international companies' investments to Mainland China.

These developments are prompting further analysis about the relative bilateral importance of Hong Kong, China's and Mainland China financial interconnectedness. In the context of weak economic conditions following the COVID-19 outbreak, significant growth slowdown, and adjustments of the financial system in Mainland China; these factors combined with rising geopolitical tensions could have major implications for markets and financial intermediaries in both jurisdictions with potential spillover effects from one economy to the other. Therefore, this annex focuses on the financial linkages between Mainland, China and Hong Kong, China through several channels:

- Capital markets: assess bilateral share of capital market activities generated in both jurisdictions and discuss implications of greater linkages and deteriorating issuer credit quality during weakening economic conditions on market conditions.

- Banking sector: assess bilateral exposure of banks in both jurisdictions and analyse consequences of potentially concentrated positions for risk management and financing channels that support economic growth.

- Offshore RMB business: analyse the implications of Hong Kong's major role in raising and investing Renminbi funds and as an intermediary that channels Renminbi funds between offshore and onshore markets; and also of the evolutions that occurred over the recent years.

- Cross border capital flows: assess trends in bilateral foreign direct investment and outward direct investment and potential implications of weakening economic conditions and rising geopolitical tensions for bilateral foreign investments, economic growth and prospects in both countries.

The overall objective is to identify the prominent links and discuss the bilateral implications of rising downside risks. 
Figure A A.1. Share of Hong Kong, China's, GDP in the Chinese economy, 1990-2020

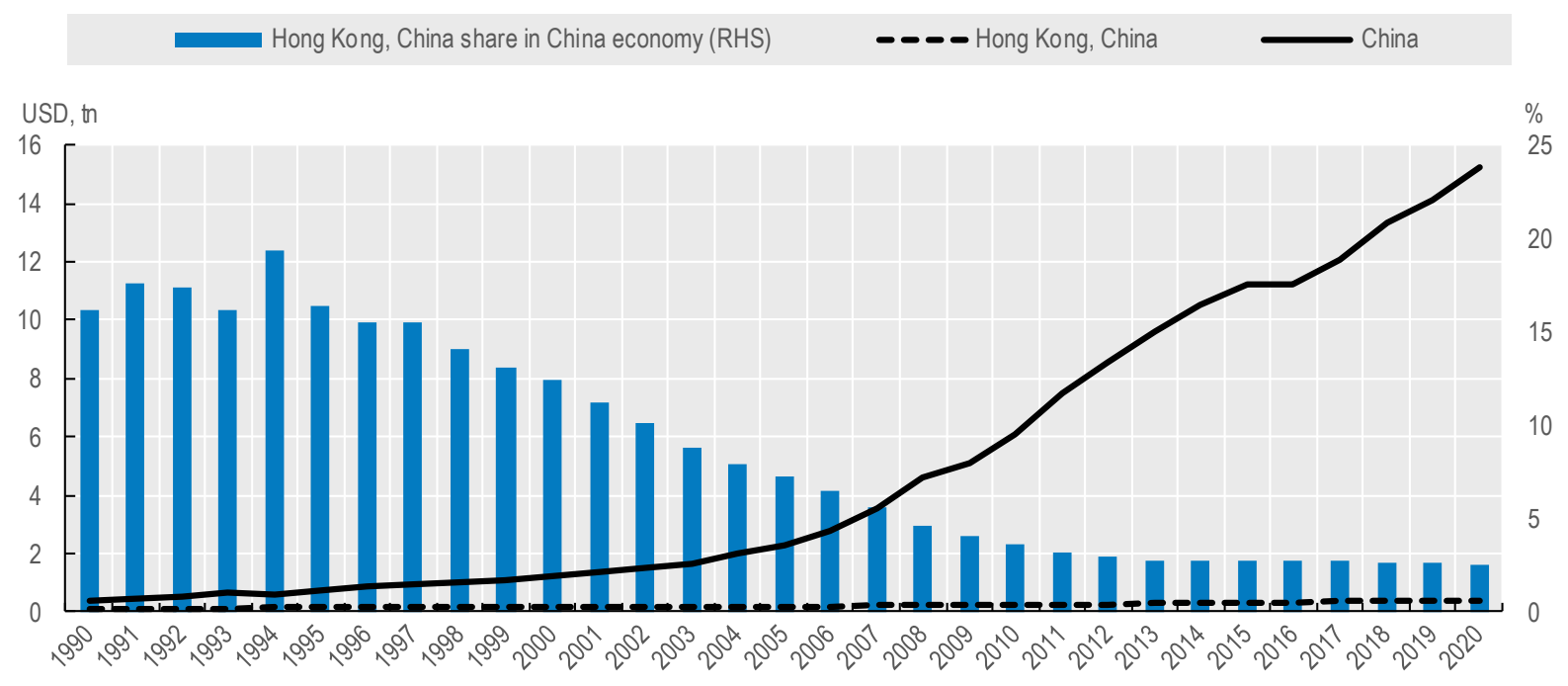

Source: IMF World Economic Database, Refinitiv, OECD calculations.

\section{Capital market financing}

The share of capital market activities generated from Mainland China firms in Hong Kong, China, is substantial.

Historically, Hong Kong, China, has been a major market for Chinese companies that raise equity financing through IPOs. ${ }^{2}$ Notably, over the period $1990-2019$, Chinese firms issued on average $90 \%$ of their offshore IPOs in Hong Kong, China (Figure A.A.2). Regarding bond financing, while the share of Chinese corporate US Dollar bond issuances in Hong Kong, China, has shrunk by almost half over the last decade, it remains elevated at $25 \%$ in 2019 (Figure A.A.3), as raising capital offshore via Hong Kong, China, provides a number of benefits to Chinese borrowers (IMF, 2020). In addition, foreign currency financing in Hong Kong, China, reduces capital outflows from China. Also, operating in Hong Kong's financial markets reduces the need for Chinese monetary authorities to use foreign exchange reserves and thereby reduces the volatility of the Chinese Renminbi exchange rate vis-à-vis the US Dollar. Much of the expansion of offshore equity and bond financing is dependent on China's growth prospects and is sensitive to the Renminbi (RMB) exchange rate expectations. Therefore, greater linkages means that should vulnerabilities in the Chinese non-financial corporate sector increase during weakening economic conditions, this could affect market sentiment and increase global risk aversion leading to more volatile market conditions in Hong Kong, China (IMF, 2016; Shaghil at al., 2019).

However, the contribution of Hong Kong, China, to overall Chinese corporate equity and bond financing has been marginal (Liu, 2020; Figure A.A.4), with Hong Kong, China's, contribution in overall Chinese corporate IPOs (i.e, including Mainland and offshore IPOs) declining sharply since a peak of $97 \%$ in 2005 to $13 \%$ in 2018 . Also, Hong Kong, China's, contributions to Mainland China's bond financing accounts only for on average $2 \%$ of overall Chinese corporate bond issuance over the period 2003-2018. The contribution of Hong Kong, China, in overall Chinese corporate equity and bond financing has been mostly weakened

\footnotetext{
${ }^{2}$ A considerable volume of "H-shares", i.e. shares of Chinese firms, is traded in Hong Kong, China. These shares are generally not permitted to be traded in Mainland China equity markets or to be converted into shares that can be traded in Mainland China. Chinese firms could access foreign equity capital through listing in Hong Kong, China since Hong Kong, China is a major world financial center with investors from around the globe participating in its markets (Elliott and Yan, 2013).
} 
by the fast growth of domestic Chinese corporate IPOs and bond issuance amid an expansion of Chinese capital markets. In addition, China's future engine for growth will likely come mainly from the growth of labour productivity (Wei et al., 2017). Therefore, rising labour costs in Mainland China are driving foreignfunded processing firms to other cheap developing countries (Pei at al., 2015) and leading to a less important role of investment from Hong Kong, China, in Mainland China.

Figure A A.2. Chinese offshore IPOs in Hong Kong, China, 1999-2019

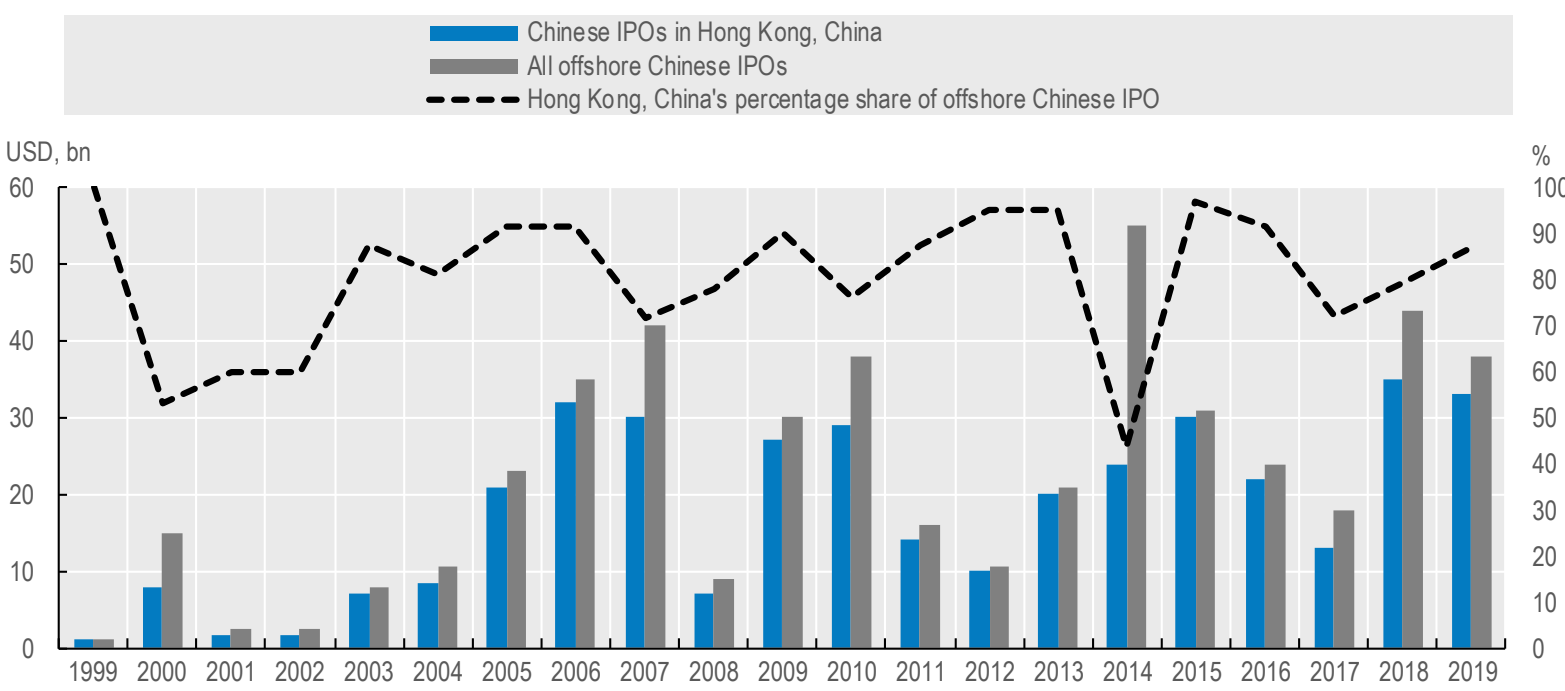

Source: Dealogic, Reuters (May 2020).

Figure A A.3. Chinese corporate US Dollar bond issuance in Hong Kong, China, 2010-2019

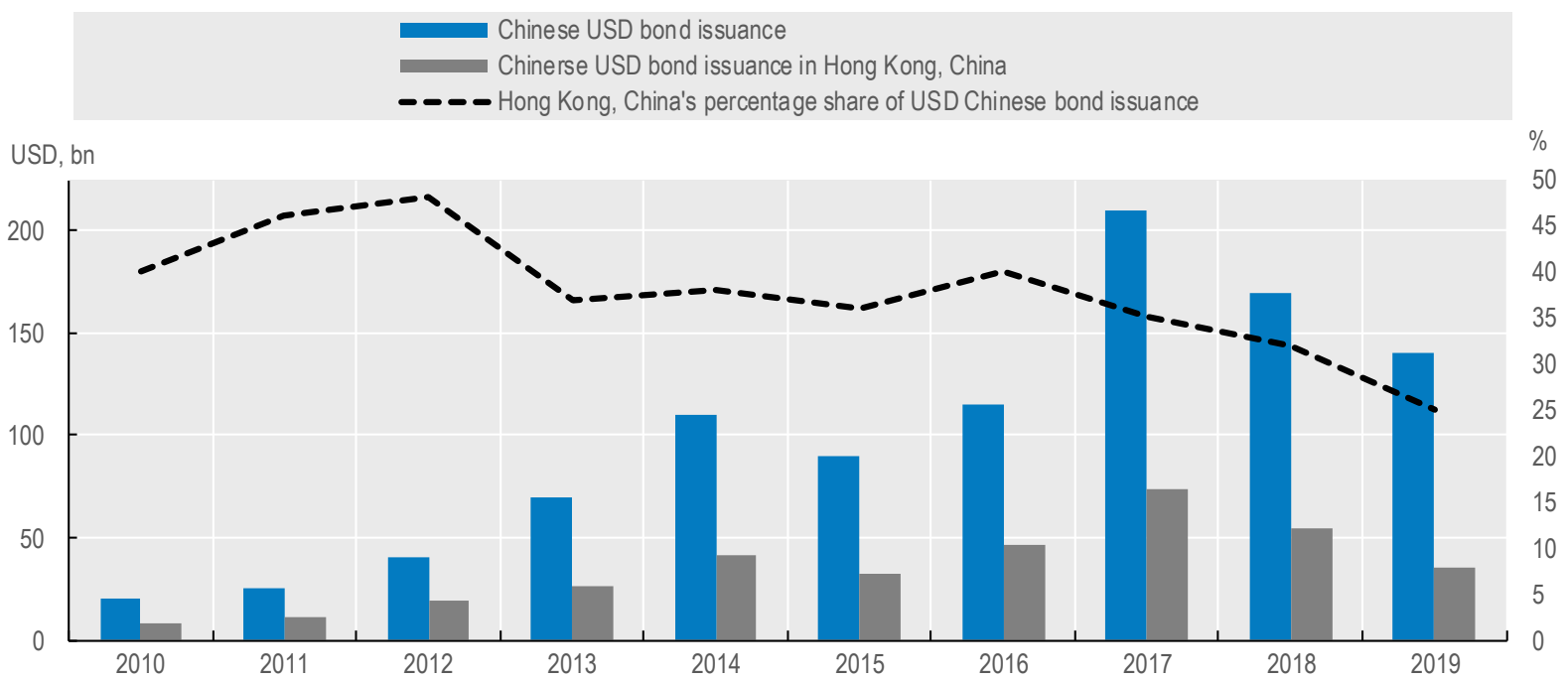

Source: Dealogic, Reuters (May 2020). 
Figure A A.4. Hong Kong, China's, contribution to Mainland China IPOs and corporate bond issuance, 2003-2018
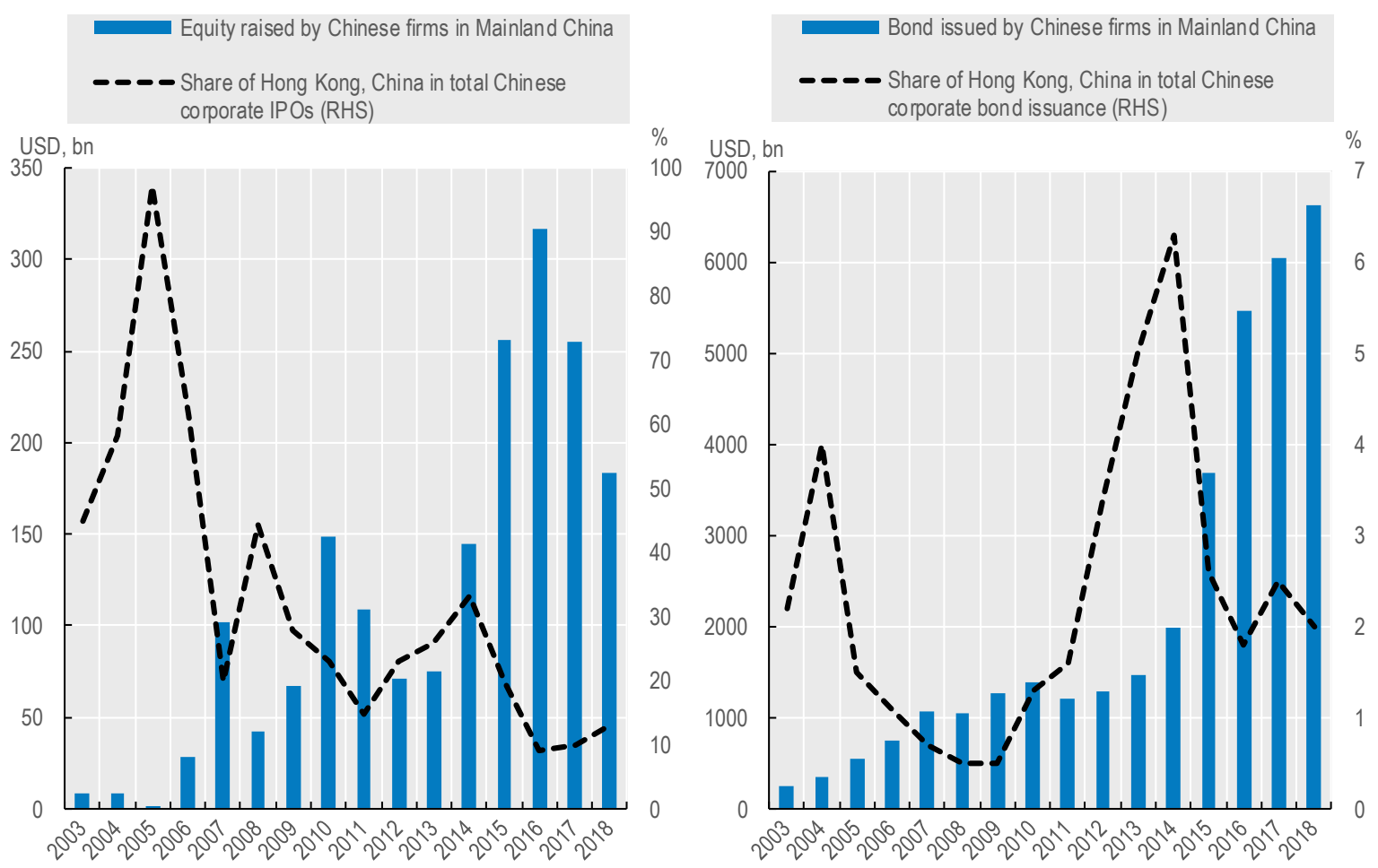

Source: Liu (2020), OECD calculations.

\section{Banking sector}

The deep linkages between Hong Kong, China, and Mainland China are also evident in the banking sector. Notably, banks in Hong Kong, China, have a substantial exposure to Mainland China. Since 2013, Mainland related loans and trade finance of Authorised Institutions ${ }^{3}$ in Hong Kong, China, has almost doubled in nominal terms and now account for substantial shares of total loans and assets, i.e. $45 \%$ and 18\% respectively, of Authorised Institutions in Hong Kong, China, in 2019 (Figure A.A.5). Yet, nonperforming loan exposures to Mainland corporates of Authorised Institutions in Hong Kong, China, remain low with an NPL ratio of $0.7 \%$, lower than that of onshore Chinese banks (IMF, 2020). The loan portfolio of Authorised Institutions in Hong Kong, China, is relatively concentrated on Mainland China's exposures, which has important implications from a risk management perspective. Therefore, banks in Hong Kong, China, are likely to be more vulnerable to any financial shocks related to the Mainland economy, and may result in contagion in the event of a financial crisis (HKMA, 2019). In fact, the HKMA (2020) report mentioned a deterioration in the default risk for the Mainland corporate sector. While corporate default risk in Mainland China improved over the second semester of 2019, mainly reflecting improved sentiment in the Mainland stock markets as a result of the expectation of reaching the US-China "Phase One" trade deal, tentative signs of deterioration have emerged since February 2020. Additionally, investors' concerns as to the extent of the COVID-19 outbreak and its associated negative impact on the financial market and

\footnotetext{
${ }^{3}$ As defined by the Hong Kong, China monetary authority (HKMA), "An authorised institution is allowed under the Banking Ordinance to carry on the business of taking deposits. Hong Kong, China maintains a Three-tier Banking System, which comprises banks, restricted licence banks and deposit-taking companies. Authorized institutions are supervised by the HKMA".
} 
economy have also emerged. This implies a need for careful credit risk management for banking institutions in Hong Kong, China, to assess their Mainland-related exposures in light of potential downside risks to the Mainland economy arising from the uncertainties surrounding the next phase of the US-China trade negotiations and the medium term effects of the COVID-19 outbreak. Specifically, downside effects could materialise through lower growth in Mainland related lending or through the deterioration of the quality of existing loans and profit outlooks of banks in Hong Kong, China.

Figure A A.5. Loan financing from Authorised Institutions in Hong, Kong, China, to Mainland China, 2013-2019

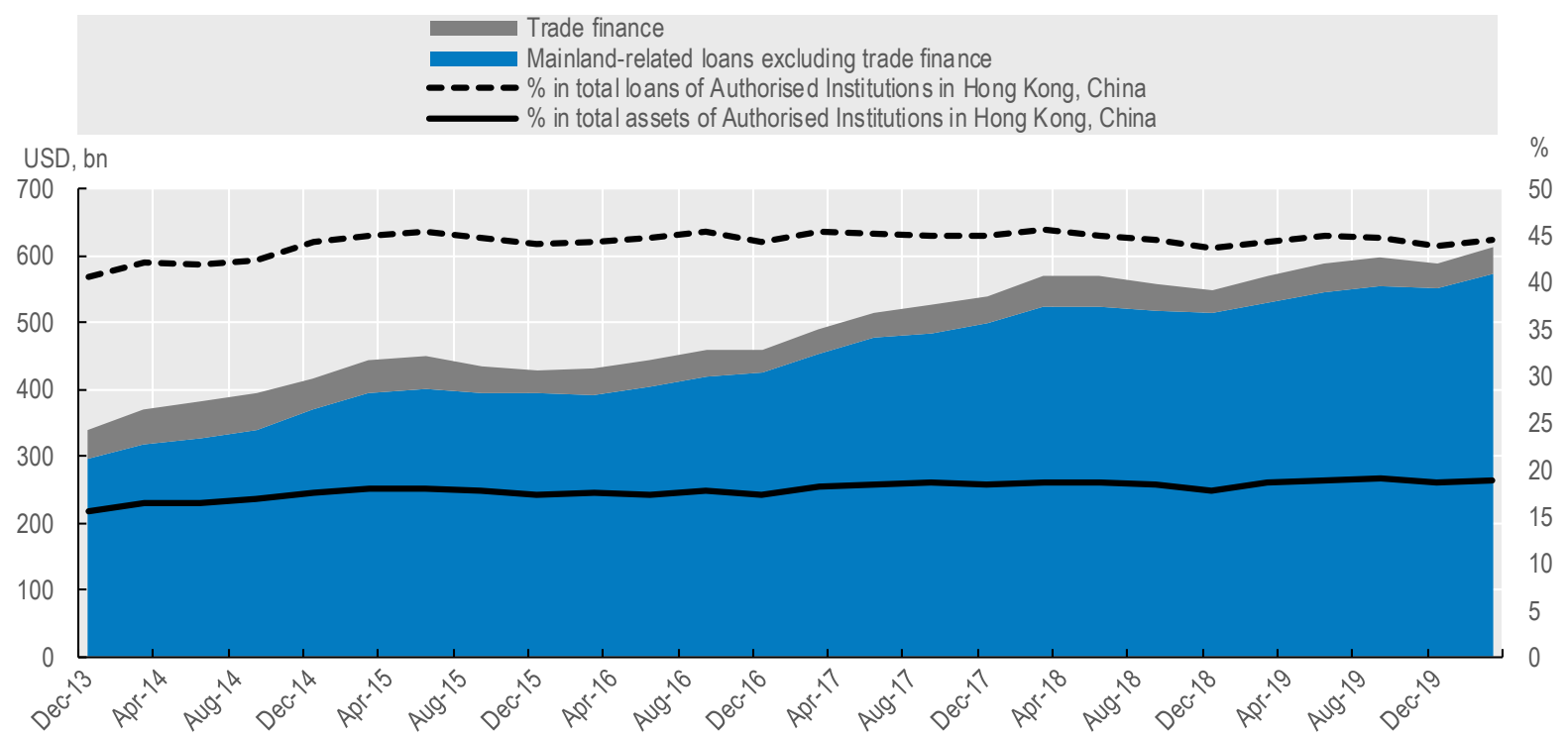

Source: Hong Kong Monetary Authority, OECD calculations.

As previously noted, the presence of Chinese banks in Hong Kong, China has become more significant. The amount of total assets of Chinese banks in Hong Kong, China, have increased dramatically over the last two decades from USD 123 billion in 1997 to 1.1 trillion in 2019, which is equivalent to $35 \%$ of total assets of foreign banks operating in Hong Kong, China (KPMG, 2017; Reuters, 2020). The size of total assets has expanded by $790 \%$ over the past 20 years. About half of Chinese banks' assets in Hong Kong, China are loans (KPMG, 2017). Chinese banks are holding more assets in Hong Kong, China than lenders from any other region and contributed to the increased segmentation in total assets and financing facilities in Hong Kong, China. This reflects the globalisation of the financial services sector in Mainland China and the multiple cooperation policies between Mainland China and Hong Kong, China. Nevertheless, Hong Kong, China, financial sector is increasingly dominated by Chinese banks. At the same time, overseas bank assets held by Mainland Chinese banks are also heavily concentrated in Hong Kong, China (Garcia Herrero, 2020). Therefore, these large exposures implies that any shifts in Hong Kong, China, as an offshore financial centre, may have substantial spillover effects on Mainland China.

\section{Offshore RMB business}

Hong Kong, China, was the first offshore market to launch Renminbi business back in 2004. Hong Kong, China, is the largest offshore Renminbi centre and is playing an increasingly significant role in the process of RMB internationalisation (Liu, 2020). The economic development of China has fostered increased use of the Renminbi internationally by corporates and international investors, which provides several benefits such as greater price transparency, shorter settlement cycles and enhanced access to financing and 
investment opportunities (HKMA, 2016). In turn, Hong Kong, China has become a global hub for Renminbi trade settlement, financing and asset management, where a wide range of Renminbi products and services is available to meet the needs of businesses, financial institutions, and investors. While the nominal value has decreased over recent years, ${ }^{4}$ the Renminbi deposit pool remains elevated and stable at around RMB 600 billion as of March 2020, i.e. foreign currency deposits accounting for $12 \%$ of total deposits of Authorised Institutions in Hong Kong, China (Figure A.A.6). Renminbi trading in Hong Kong, China, reflects the role of the city as a platform for raising and investing Renminbi funds and also, as an intermediary that channels Renminbi funds between offshore and onshore markets. Ultimately, foreign investments are beneficial for China's economic development and growth. While Hong Kong is the largest offshore RMB centre, this position should not be simply taken for granted. Renminbi is also heavily traded in other major global financial centers such as London, Singapore, New York, Paris and Chinese Taipei (BIS, 2016). Therefore, Hong Kong, China will face increasing competition for Renminbi business. Based on comprehensive data from the Triennial Central Bank Survey of Foreign Exchange and Over-the-Counter Derivatives Market Activity, Cheung et al. (2019) argue that "while the RMB internationalisation strategy may have given a head start to Hong Kong, China and other Asian trading centers, if the RMB becomes a key international currency, market forces, not policy, will determine where it is traded."

\section{Figure A A.6. Renminbi deposits in Hong Kong, China, 2004-2019}



Source: Hong Kong Monetary Authority, OECD calculations.

\section{Cross border capital flows}

Hong Kong, China, is a major source of foreign direct investment (FDI) to Mainland China and a major destination of outward direct investment (ODI) from Mainland China. Since 2005, the share of FDI from Hong Kong, China, to Mainland China has continuously risen (Figure A.A.7). In 2018, Hong Kong, China, was the source of almost $70 \%$ of FDI in Mainland China. Most of Hong Kong's manufacturing investments in Mainland China are labour-intensive and export-oriented because of the attractiveness of relatively cheaper labour and land costs in Mainland China (Zhang and Yuk, 1998). Also, free trade agreements signed under the Closer Economic Partnership Arrangement (CEPA) since 2003 have helped attract FDI from Hong Kong, China, to Mainland China.

\footnotetext{
${ }^{4}$ A substantial drawdown in offshore Renminbi deposits materialised at beginning 2016 following the implementation of increasing capital controls from China that lead to a substantial devaluation of the Renminbi (Financial Times, 2017).
} 
Hong Kong, China is the largest destination for outward direct investments (ODI) from China (Figure A.A.8). In 2018, ODI from China in Hong Kong, China, represented $60 \%$ of total Chinese ODI, exceeding related shares of top destinations such as Singapore (6\%), the United States (5\%), the Netherlands and Australia (4\% each). The majority of Chinese ODI went to services, in particular leasing and business services (OECD, 2019d) reflecting the role of Hong Kong, China, as an intermediary services hub. Also, as documented by OECD (2019), a large share of ODI from China occurs through M\&A transactions and greenfield investments, with Hong Kong, China, being one of the top-targeted destinations for these activities.

Weakening economic conditions and rising geopolitical tensions give rise to downside risks for bilateral foreign investments. For example, a fall in foreign investment may disrupt the engine of economic growth and worsen economic prospects in both countries.

\section{Figure A A.7. Foreign direct investment from Hong Kong, China to Mainland China and outward direct investment from Mainland China to Hong Kong, China, 1990-2018}

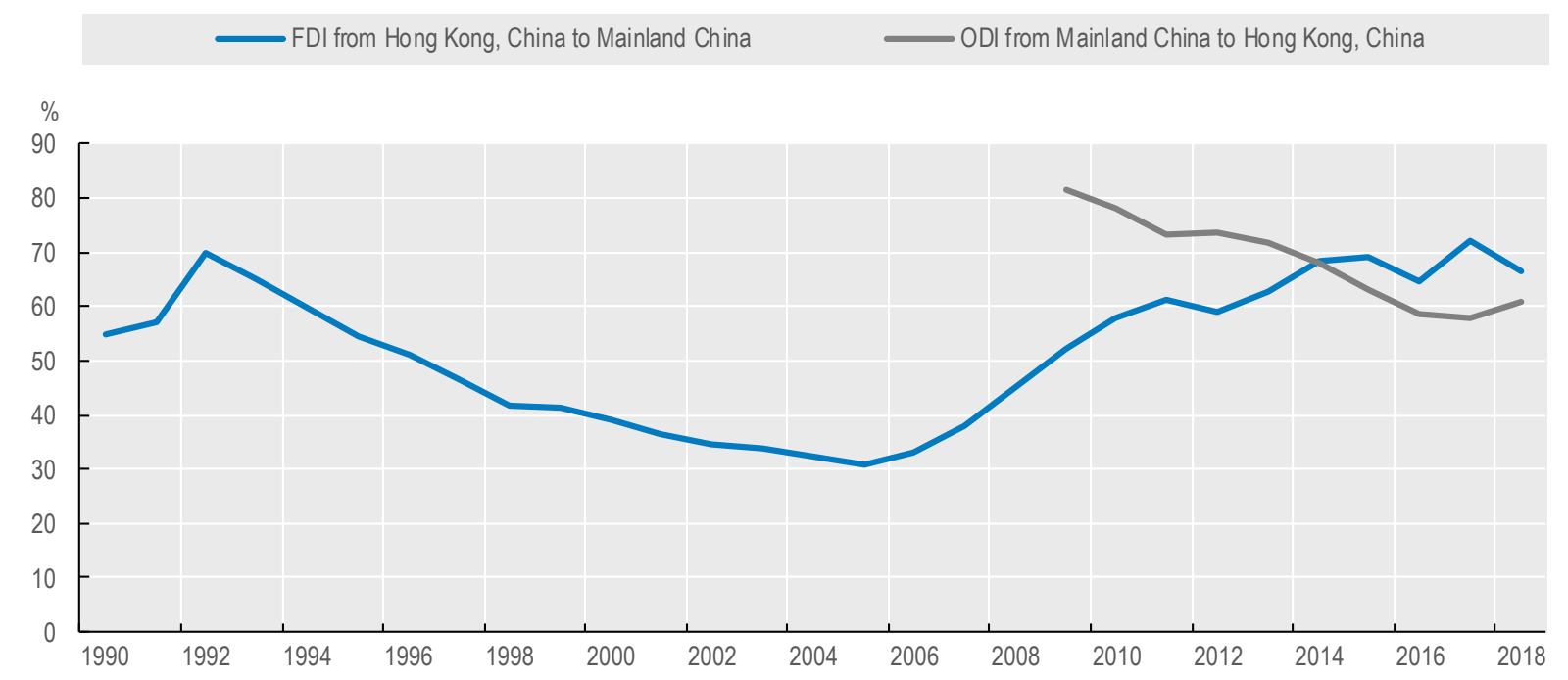

Note: This figure shows foreign direct investment from Hong Kong, China to Mainland China and outward direct investment from Mainland China to Hong Kong, China. Foreign direct investment from Hong Kong, China to Mainland China is defined as the share of the FDI that has come from Hong Kong, China to invest in Mainland China over the total FDI Mainland China has attracted. Outward direct investment from Mainland China to Hong Kong, China is defined as the share of ODI that has come from Mainland China to invest in Hong Kong, China over total ODI that has come from Mainland China to invest overseas.

Source: National Bureau of Statistics of China, IMF Coordinated Direct Investment Survey (CDIS) database, OECD calculations. 
Figure A A.8. Outward direct investment from China to selected destinations, 2018

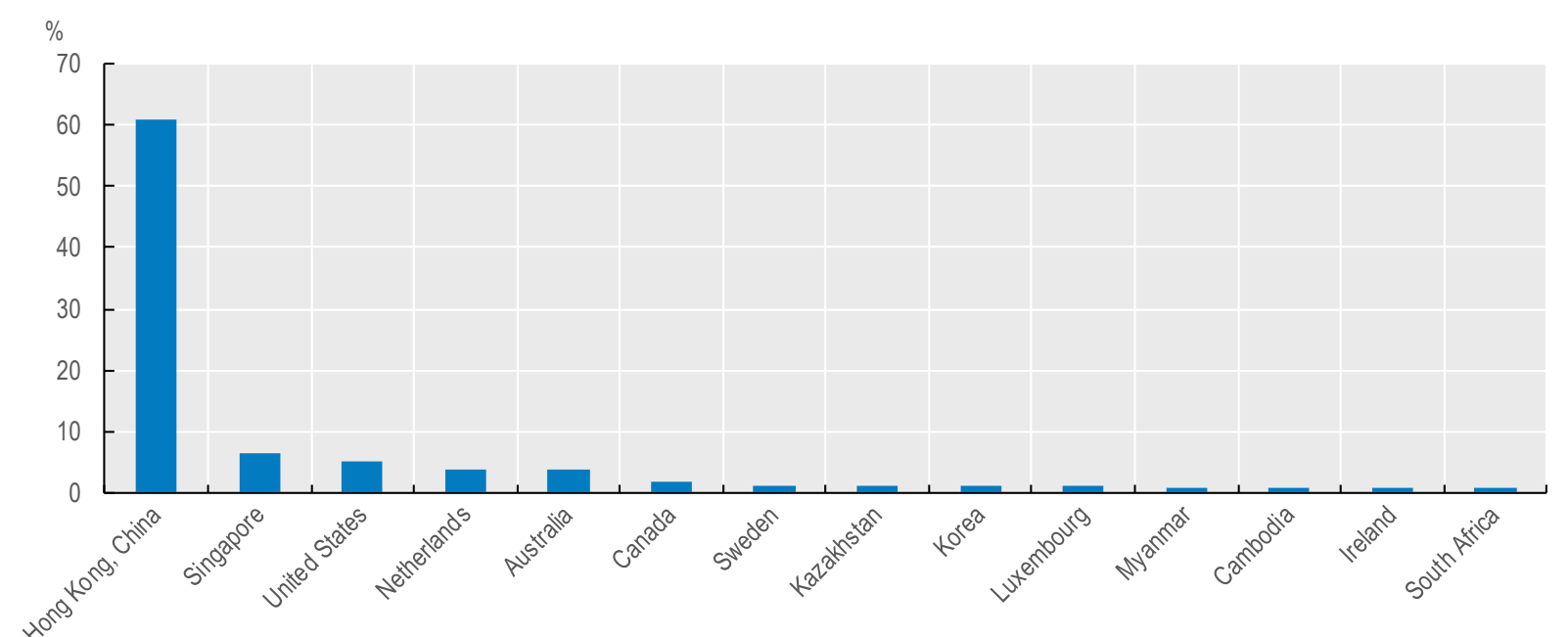

Note: This figure shows Hong Kong, China share in China's outward direct investment (ODI). It is defined as the share of ODI that has come from Mainland China to invest in Hong Kong, China over total ODI that has come from Mainland China to invest overseas.

Source: IMF Coordinated Direct Investment Survey (CDIS) database, OECD calculations.

Overall, deep bilateral financial linkages between Hong Kong, China, and China are materialising through cross border capital flows and bank exposures. Also, substantial capital market activities generated from Mainland China firms in Hong Kong, China and the major role of Hong Kong, China in the internationalisation of the Renminbi are strengthening such bilateral relationships. The role of Hong Kong, China in channelling foreign equity and debt financing to Chinese corporates remain substantial (The Economist, 2020) with major implications for China economic growth; despite increasing competition from other major financial centers for Renminbi trading. In this context, Mainland China would face substitution issues if the role of Hong Kong, China as a major financial hub would be challenged. 


\section{Annex B. ICOs and SME financing}

Initial Coin Offerings (ICOs) are sales of blockchain-based digital tokens (i.e. cryptocurrency, utility and security tokens) that are related to a specific project, company or asset. In most cases, ICO ventures often resemble start-ups that conventionally finance themselves through angel or venture capital investments. In contrast to IPO financing, ICOs are available to small businesses and also start-ups at a much earlier stage in their company and product development cycle. ICOs can raise substantial funds for start-ups before products are even developed and well before the company reaches the size and level of turnover that an IPO often requires. Companies issuing ICOs are not required to use intermediation services, and can undertake an ICO at a significantly lower cost today than other financing methods. One notable feature of ICOs is that the capital investment is not always given in return for an equity share.

\section{ICOs for SME financing}

As documented in an OECD report (2019c), regulated Initial Coin Offerings (ICOs) can be a more inclusive financing vehicle for small businesses, by allowing small retail investors to participate in the financing of projects enabled by Distributed Ledger Technologies (DLTs) and the blockchain.

ICOs in their current shape and form, however, carry important risks for the SME issuers and investors subscribing to token offerings. The uncertainty of the applicable regulatory framework, coupled with the lack of financial consumer protection safeguards, limitations in the structuring of ICOs and operational risks related to DLTs, expose investors subscribing to ICO offerings and SMEs issuing tokens to significant risks.

Clarity in the regulatory and supervisory framework applied to ICOs as a stepping-stone to the safer use of token issuance for financing purposes. Standardised disclosure requirements, and enhanced investor protection for retail investors, coupled with greater awareness of risks by retail investors, can safeguard their informed participation in such financing. AML/CFT requirements on ICO issuances are equally important, given the relevant issues observed in the crypto-assets space.

A delicate balance needs to be achieved in the development or application of regulatory and supervisory requirements that will not deprive the ICO mechanism of its speed and cost benefits, and proportionality could be considered. Even in a more mature, safe and regulated form, however, ICOs have few prospects of becoming a 'mainstream' financing instrument, as they can only be meaningful to products and services that run on DLTs, to allow for the realisation of network effects. 
Figure A.B.1. The ICO process and related risks

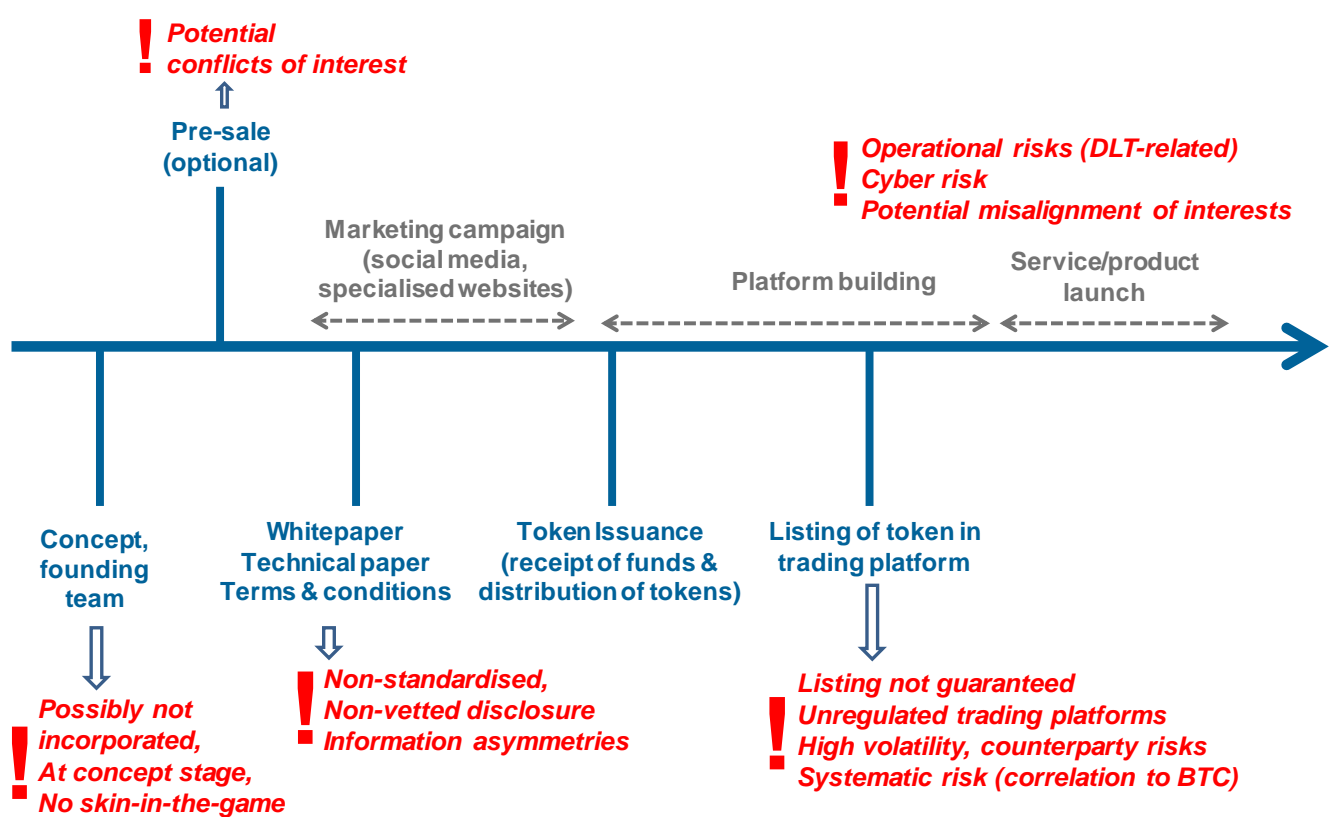

Source: OECD (2019c), Initial Coin Offerings (ICOs) for SME Financing. 


\section{Annex C. List of previously published working papers}

The full series is listed below in chronological order. Prior to March 2010, the series was named OECD Working Papers on Insurance and Private Pensions. All working papers can be accessed online at: www.oecd.org/daf/fin/wp.

2020

WP.44: Structural developments in global financial intermediation - The rise of debt and non-bank credit intermediation

2017

WP.43: Financial Education for MSMEs and Potential Entrepreneurs

WP.42: Behavioural Economics and Financial Consumer Protection

2016

WP.41: Unleasing the Export Potential of SMEs in Greece

WP.40: Financial Education Policies in Asia and the Pacific

2015

WP39: Financial Education for Long-term Savings and Investments: A Review of Research and Literature

WP38: Financial Education for Migrants and their Families

WP37: The Bitcoin Question: Currency versus Trust-less Transfer Technology

2013

WP36: Institutional Investors and Infrastructure Financing

WP35: Institutional Investors and Green Infrastructure Investments: selected case studies

WP34: Promoting Financial Inclusion through Financial Education

WP33: Financial Education in Latin America and the Caribbean

WP32: Pension Fund Investment in Infrastructure: A Comparison between Australia and Canada

WP31: Policyholder Protection Schemes: Selected Considerations

2012

WP30: The Effect of Solvency Regulations and Accounting Standards on Long-Term Investing

WP29: Trends in Large Pension Fund Investment in Infrastructure

WP28: Communicating Pension Risk to DC Plan Members: The Chilean Case of a Pension Risk Simulator 
WP27: The Role of Funded Pensions in Retirement Income Systems: Issues for the Russian Federation

WP26: Infrastructure Investment in New Markets: Challenges and Opportunities for Pension Funds

WP25: The Status of Financial Education in Africa

WP24: Defining and Measuring Green Investments: Implications for Institutional Investors' Asset Allocations

WP23: The Role of Institutional Investors in Financing Clean Energy

WP22: Financial Education, Savings and Investments

WP21: Identification and Assessment of Publicly Available Data Sources to Calculate Indicators of Private Pensions

WP20: Coverage of Private Pensions Systems: Evidence and Policy Options

WP19: Annual DC Pension Statements and the Communications Challenge

WP18: Lessons from National Pensions Communication Campaigns

WP17: Review of the Swedish National Pension Funds

WP16: Current Status of National Strategies for Financial Education

WP15: Measuring Financial Literacy: Results of the OECD International Network on Financial Education Pilot Study

WP14: Empowering Women through Financial Awareness and Education

WP13: Pension Fund Investment in Infrastructure: Policy Actions

WP12: Designing Optimal Risk Mitigation and Risk Transfer Mechanisms to Improve the Management of Earthquake Risk in Chile

\section{1}

WP11: The Role of Guarantees in Defined Contribution Pensions

WP10: The Role of Pension Funds in Financing Green Growth Initiatives

WP9: Catastrophe Financing for Governments

WP8: Funding in Public Sector Pension Plans - International Evidence

WP7: Reform on Pension Fund Governance and Management: The 1998 Reform of Korea National Pension Fund

2010

WP6: Options to Improve the Governance and Investment of Japan's Government Pension Investment Fund

WP5: The New IAS 19 Exposure Draft

WP4: The EU Stress Test and Sovereign Debt Exposures

WP3: The Impact of the Financial Crisis on Defined Benefit Plans and the Need for CounterCyclica Funding Regulations

WP2: Assessing Default Investment Strategies in Defined Contribution Pension Plans 
WP1: Framework for the Development of Financial Literacy Baseline Surveys: A First International Comparative Analysis

\section{OECD Working Papers on Insurance and Private Pensions}

2010

WP41: Policy Action in Private Occupational Pensions in Japan since the Economic Crisis of the 1990s

WP40: Pension Funds' Risk-management Framework: Regulation and Supervisory Oversight

WP38: Managing Investment Risk in Defined Benefit Pension Funds

\section{9}

WP37: Investment Regulations and Defined Contribution Pensions

WP36: Private Pensions and Policy Responses to the Financial and Economic Crisis

WP35: Defined-contribution (DC) arrangements in Anglo-Saxon Countries

WP34: Evaluating the Design of Private Pension Plans

WP33: Licensing Regulation and the Supervisory Structure of Private Pensions

WP32: Pension Fund Investment in Infrastructure 


\section{Notes}

${ }^{1}$ For further details on Asian economic outlook and the evolution of economic growth and financial development in the region, see OECD (2019a), Economic Outlook for Southeast Asia, China and India 2020: Rethinking Education for the Digital Era, OECD Publishing, Paris, https://doi.org/10.1787/1ba6cde0en.

${ }^{2}$ For further details, see Hack and Close (2013).

${ }^{3}$ For further details, see OECD (2018c and 2019b).

${ }^{4}$ For a detailed discussion on how debt levels can signify sustainability problems, see Reinhart and Rogoff (2011 and 2008).

${ }^{5}$ For further details on funding needs for infrastructure in the Asia region, see OECD (2018a) Business and Finance Outlook 2018, Chapter 2.

${ }^{6}$ For further details on these implemented strategies and policy recommendations, see OECD (2018a) Business and Finance Outlook 2018, Chapter 1 and 2.

${ }^{7}$ For Further details, see McKinsey (2013).

${ }^{8}$ The bond market in China is divided into three categories: (i) the China Inter-Bank Bond Market (CIBM), (ii) the exchange bond market (including the Shanghai Stock Exchange (SSE) and the Shenzhen Stock Exchange (SZSE)) and (iii) the commercial banks' counter market. In 1997, the national interbank bond market was established and then developed rapidly. In 2001, the volume of bond issuance, trading, and custody in the interbank bond market surpassed that of the exchange bond market. Since then, China has formed a bond market system which is dominated by the interbank market and supplemented by the exchange and commercial bank OTC markets. For more details, see Asian Development Bank (2019) and Lin et al. (2019).

${ }^{9}$ Fitch Ratings has reviewed the 26 defaults by Chinese SOEs between the start of 2015 and the end of February 2020, in both onshore and offshore corporate bonds. Fitch Ratings has identified five factors that may be associated with SOEs' potential for default: sectoral overcapacity, the degree of commercialisation, the parent entity's capacity for support, the complexity of ownership structures, and the distance of the entity's ownership from the ultimate state parent. Financial pressure on China's SOEs has risen as the authorities seek to reduce risks in the financial sector and limit the moral hazard associated with implicit support for SOEs.

${ }^{10}$ For further details, see OECD (2020).

${ }^{11}$ For further details, see Moody's (2020). 
12 This measure is based on the FSB Policy Framework (2013), in which non-bank financial entities are classified with reference to five economic functions (i.e., management of collective investment vehicles with features that make them susceptible to runs, loan provision that is dependent on short-term funding, intermediation of market activities that is dependent on short-term funding or on secured funding of client assets, facilitation of credit creation and securitisation-based credit intermediation and funding of financial entities), each of which involves non-bank credit intermediation that may pose risks to financial stability.

${ }^{13}$ Further detailed information on the mapping of China shadow banking are presented in Ehlers et al. (2018).

${ }^{14}$ Chinese banks are offering two main types of WMPs. First, the principal or return-guaranteed WMPs (PRG-WMPs) that entail full bank guarantees either on the principal or on the return. They are recorded on banks' balance sheets along with the underlying investment which they finance. PRG-WMPs are akin to negotiable certificates of deposit (NCD) and subject to normal banking regulations. They are therefore do not consider to be part of shadow banking. Second, banks offer non-principal guaranteed WMPs with no explicit bank guarantees, which are not recorded on banks' balance sheets. The underlying investment of the non-principal guaranteed WMPs is usually held by a channelling company (i.e., banks' investment or wealth management branch) but the issuing bank normally retains full control over the investment. Effectively, banks act as asset managers, charging fees to investors, without being subject to regulatory restrictions, except for those governing the admissible design of WMPs.

${ }^{15}$ Bloomberg (2019).

${ }^{16} \mathrm{~A}$ large share of the proceeds from WMPs have been invested in the bond market (Ehlers et al., 2018).

${ }^{17}$ For further details on current implemented shadow banking regulation in China, see OECD (2018a) Business and Finance Outlook 2018 (Chapter 1 and 2) and Li, C., 2016, "The Changing Face of Shadow Banking in China", Asia Focus, Federal Reserve Bank of San Francisco.

${ }^{18}$ These estimates are based on key findings from the Cambridge Centre for Alternative Finance annual global survey of online alternative financing activities in more than 185 countries. In all, 1,227 unique firms contributed to this study, providing 2,322 firm-level observations globally. Investigating in crowdfunding, peer-to-peer marketplace lending or related capital raising activities, the study shows that $47 \%$ of the firms were operating in two or more countries or jurisdictions. Breaking the survey sample down by key markets, this study captured 632 firm-level observations in Europe, 87 in the United Kingdom, 438 in China, 334 in the Asia-Pacific, 270 in Latin America and the Caribbean, 237 in the Middle East \& Africa, and 143 in the United States and Canada. The purpose of this global report is to shed light on the evolving landscape and market dynamics of the online alternative finance industry which are now providing substantial sources of funding for consumers, start-ups, small and medium sized enterprises, and industrial verticals ranging from manufacturing sector to creative industries.

${ }^{19}$ For further details, see FSB (2017c) and BIS (2019).

${ }^{20}$ For further details, see Claessens et al. (2018).

${ }^{21}$ For further details, see CCAF (2018).

${ }^{22}$ For further details, see Shen and Li (2018).

${ }^{23}$ Some Fintech firms guarantee a certain level of return to investors and mitigate credit risk in several ways including taking guarantee from third party companies for loan principal and interest or requiring 
borrowers to provide collateral. Although third party guarantees can help mitigate borrower credit risk to some extent, the counterparty risk is transferred to the guarantee companies and the number of high quality companies is limited. At times, the guarantee company may be indirectly owned by the Fintech firm (Chuen and Deng, 2017).

${ }^{24}$ For further details, see CCAF (2018).

25 The China Banking Regulatory Commission has issued a series of regulations and Guidelines. On August 24, 2016, the China Banking Regulatory Commission jointly issued the Interim Measures for the Management of Marketplace Lending Information Intermediary Business Activities, which established the marketplace lending industry supervision system and business rules. Since then, the China Banking Regulatory Commission has successively issued the Guidelines for the Registration and Registration of Marketplace Lending Information Intermediaries, the Guidelines for the Deposit and Management of Marketplace Lending Funds, and the Interim Measures for the Management of Business Activities of Marketplace Lending Information Intermediaries.

${ }^{26}$ For example, new rules prohibited existing practices by FinTech credit firms such as raising funds for themselves or guaranteeing investments, and mandated the depositing of client funds. Further specific measures were taken in 2017: new student loans were banned and the regulation for payday loans was tightened.

${ }^{27}$ For further details, see PBC-CSRC, 2018. Guiding opinions on further regulating the services relating to the internet sales and redemption of money market funds.

http://www.csrc.gov.cn/pub/zjhpublic/zjh/201806/t20180601_339014.htm.

${ }^{28}$ For further details, see OECD (2019b).

${ }^{29}$ For further details, see Ernst and Young (2020).

${ }^{30}$ Annex B provides detailed information about global ICOs market that is a further potential sources of finance to businesses, including to SMEs.

${ }^{31}$ For further details, see OECD (2019). 